\title{
The Identification of Novel Biomarkers Is Required to Improve Adult SMA Patient Stratification, Diagnosis and Treatment
}

\author{
Piera Smeriglio ${ }^{1, *(\mathbb{C})}$, Paul Langard ${ }^{1}\left(\mathbb{D}\right.$, Giorgia Querin ${ }^{1,2,3}$ ) and Maria Grazia Biferi ${ }^{1, *(\mathbb{C})}$ \\ 1 Centre of Research in Myology, Institute of Myology, Sorbonne Université, INSERM, 75013 Paris, France; \\ p.langard@institut-myologie.org (P.L.); g.querin@institut-myologie.org (G.Q.) \\ 2 Association Institut de Myologie, Plateforme Essais Cliniques Adultes, 75013 Paris, France \\ 3 APHP, Service de Neuromyologie, Hôpital Pitié-Salpêtrière, 75013 Paris, France \\ * Correspondence: p.smeriglio@institut-myologie.org (P.S.); mg.biferi@institut-myologie.org (M.G.B.)
}

Received: 12 June 2020; Accepted: 24 July 2020; Published: 29 July 2020

\begin{abstract}
Spinal muscular atrophy (SMA) is currently classified into five different subtypes, from the most severe (type 0 ) to the mildest (type 4) depending on age at onset, best motor function achieved, and copy number of the SMN2 gene. The two recent approved treatments for SMA patients revolutionized their life quality and perspectives. However, upon treatment with Nusinersen, the most widely administered therapy up to date, a high degree of variability in therapeutic response was observed in adult SMA patients. These data, together with the lack of natural history information and the wide spectrum of disease phenotypes, suggest that further efforts are needed to develop precision medicine approaches for all SMA patients. Here, we compile the current methods for functional evaluation of adult SMA patients treated with Nusinersen. We also present an overview of the known molecular changes underpinning disease heterogeneity. We finally highlight the need for novel techniques, i.e., -omics approaches, to capture phenotypic differences and to understand the biological signature in order to revise the disease classification and device personalized treatments.
\end{abstract}

Keywords: spinal muscular atrophy; adult patients; disease heterogeneity; Nusinersen; disease modifiers; functional outcomes; biomarkers; epigenetic changes; -omics approaches

\section{Introduction}

Spinal muscular atrophy (SMA) is a neurodegenerative disease affecting motoneurons (MN) in the brainstem and spinal cord caused by the homozygous mutation of the Survival of Motor Neuron 1 (SMN1) gene [1]. The disease presents with a wide spectrum of clinical severity and patients are classified into five types, depending on the age of onset and motor milestones achieved. Patients with type 0 SMA are the most extreme cases with death early after birth. Severity decreases from type 1 to type 4 SMA, which only presents mild symptoms starting at the adult age and have a very slow evolution over time (reviewed in [2], see Table 1 and Figure 1A). Attempts to explain this phenotypic variability have been made and several disease modifiers are known [3]. The most widely accepted modifier is the copy number of the SMN2 gene, a centromeric paralog of SMN1. Following a cytosine to thymine transition in exon 7, which creates an exon splicing suppressor (ESS), the transcription of SMN2 leads to $90 \%$ of transcripts coding for a truncated SMN protein. The remaining $10 \%$ produces a full-length (FL) SMN protein, thus inducing low levels of SMN expression.

SMN2 copy number is directly correlated with the SMN expression level; therefore, a higher copy number is associated with a milder phenotype [4]. SMN2 copy number is used, together with age of onset and motor abilities achieved, as an additional parameter to stratify SMA patients (Table 1 and 
Figure 1B). This additional factor is, however, still insufficient to explain the phenotypic variability among siblings carrying the same mutation in SMN1 and same SMN2 copy number $[5,6]$.

Table 1. Current classification of spinal muscular atrophy (SMA) patients in $\mathbf{5}$ types. The subtypes, age of onset (mo.: months; y.: years), level of motor functions, life expectancy, and frequency of SMN2 copy number $(S M N 2 \mathrm{cn})$ are reported [7]. Background colors are used to differentiate SMA types.

\begin{tabular}{|c|c|c|c|c|c|}
\hline SMA Type & Subtype & Age of Onset & Level of Motor Functions & Life Expectancy & SMN2cn (\%) \\
\hline $0 / 1 a$ & & pre-natal & Need respiratory assistance & $<1$ month & \\
\hline \multirow[t]{3}{*}{1} & & $0-6 \mathrm{mo}$ & Cannot sit independently & $<2$ years & $2(73.4 \%)$ \\
\hline & $1 b$ & & $\begin{array}{l}\text { Absence of head control and } \\
\text { ability to roll over }\end{array}$ & & \\
\hline & $1 \mathrm{c}$ & & $\begin{array}{l}\text { Sometimes gain head control } \\
\text { or the ability to roll from } \\
\text { supine to prone position }\end{array}$ & & \\
\hline \multirow[t]{3}{*}{2} & & $<18 \mathrm{mo}$ & Cannot stand independently & $>2$ years & $3(81.8 \%)$ \\
\hline & $2 a$ & & Independent sitting lost & & \\
\hline & $2 b$ & & $\begin{array}{l}\text { Independent } \\
\text { sitting conserved }\end{array}$ & & \\
\hline \multirow[t]{2}{*}{3} & & $>18 \mathrm{mo}$ & $\begin{array}{l}\text { Able to stand and walk } \\
\text { independently }\end{array}$ & Adulthood & $\begin{array}{l}3-4 \\
(50.6 \% ; 45.5 \%)\end{array}$ \\
\hline & $\begin{array}{l}3 a \\
3 b\end{array}$ & $\begin{array}{l}18 \mathrm{mo} \cdot-3 \mathrm{y} \\
>3 \mathrm{y}\end{array}$ & & & \\
\hline 4 & & $>20 \mathrm{y}$ & Weaknesses in lower limbs & Adulthood & \\
\hline
\end{tabular}

In the last few years, other gene modifiers have been described, such as Plastin 3 (PLS3) [8], Coronin 1C (CORO1C) [9], and Neurocalcin Delta (NCALD) [10] (Figure 1C). It remains puzzling to note that the expression changes of these genes do not fully explain the phenotypic heterogeneity in the SMA population. Additional modifier conditions to be considered are (i) the environmental factors that may influence the final phenotype of the patients [11] and (ii) the differential vulnerability of MN subtypes that is affected by the level of SMN protein [12,13]. Although all of these factors are known contributors to the differential disease severity, other unknown aspects might need to be considered in the future for a comprehensive description of the disease.

Recent advances in the SMA field have led to the development of therapeutic approaches, aiming to increase the level of SMN protein targeting SMN2 through an antisense (AS) oligonucleotide $[14,15]$ or a pre-mRNA splicing modifier drug [16], as well as inducing the restoration of the SMN protein via gene therapy [17].

Approved by the Food and Drug Administration in 2016, Nusinersen is an AS oligonucleotide that targets exon 7 of SMN2 to facilitate its inclusion and trigger a higher production of the full-length SMN transcript. Nusinersen is administered via intrathecal injection, directly into the cerebrospinal fluid (CSF), in a two-phase treatment: (1) a loading phase of four doses 14, 14, and 30 days apart followed by (2) a maintenance phase with a dose every four months. Treatment with Nusinersen showed very promising results in young type 1 patients $[14,15]$ and some positive effects in type 2 and 3 patients (no type 4 patients have been enrolled in clinical trials to date) [18-20]. Unexpectedly, the latter studies which include adult SMA patients ( $>18$ years old) showed that their response to Nusinersen, evaluated as motor function improvement, was highly variable, with $40-50 \%$ of responders at best [18-20]. These observations suggest that factors modulating response to treatment, in particular for the older patients, remains to be uncovered. Moreover, due to the lack of natural history data and the higher heterogeneity among the adult SMA patient population, therapeutic monitoring of these patients is particularly challenging [21,22]. Therefore, an exceptional effort is needed to facilitate further characterization of the clinical and molecular profiles of these SMA patient populations.

In this context, the identification of novel biomarkers and precise methods for functional outcomes evaluation are unmet needs. Reaching these goals will provide the means to (i) redefine patients' classification, (ii) characterize the full molecular profile of therapy responders or non-responders, and 
(iii) determine inclusion criteria in clinical trials and treatment protocols. Therefore, several types of biomarkers have been evaluated in order to capture patients' pre-existing differences and their response to treatment.

As previously reviewed, biomarkers can be classified as biomolecular, mirroring the molecular changes, and functional to picture the phenotypic disease progression [23]. This review will initially focus on the most promising biomarkers for adult SMA ( $>18$ years old). Data on therapeutic monitoring are gathered through the different studies reporting results from treatment with Nusinersen, the most widely used therapy for SMA worldwide up to date. Current available information on the molecular signature of SMA patients will be then presented, including gene modifiers, epigenetic changes, and putative molecular biomarkers. Furthermore, although various molecular biomarkers have been proposed in the last few years as possible candidates, no factor has been proven to date to faithfully follow the disease progression in all SMA types. Therefore, here we will also discuss the potential of unbiased -omics (e.g., proteomics) approaches as valuable tools for the identification of novel SMA-specific biomarkers.

In perspective, an in-depth analysis of both functional outcomes' evaluation and molecular biomarkers, would help determine the differences that define the wide spectrum of clinical features among SMA patients and their disparate response to treatment. Efforts in this direction could lead to the development of personalized medicine approaches in the future.

\section{Evaluation of Functional Outcomes in Adult Patients}

Functional outcomes are essential to monitor disease progression and to precisely understand where the patient stands in the wide spectrum of the disease phenotypes. For chronic diseases, the longitudinal study of functional outcomes contributes to define the natural history of the disease and can also be used to monitor the therapeutic response. In SMA, several tests have been used for diagnosis, prognosis, or therapeutic monitoring. These tests have frequently turned out to be unadaptable to the adult SMA patient population ( $>18$ years of age) due to its high heterogeneity. This group of patients still needs a precise characterization and patient-specific therapeutic adjustments or development. Therefore, this section of the review will focus on functional outcomes reported to reliably assess the Nusinersen response in SMA adult patients. Data collected in younger patients will be presented as comparison.

Gradual motor function loss is a common feature of all SMA types. While adult patients are generally classified as less severe cases than type 1 children, their motor function also declines progressively [24]. The motor abilities can be monitored by a variety of measurements, spanning from scales assessing the general mobility or muscle function, to the more global walking analysis. Respiratory function is also frequently assessed in adult SMA patients, as respiratory failure is still the most frequent cause of morbidity in SMA patients [25]. In this section, we are documenting functional outcomes to assess (i) general mobility; (ii) motricity of the upper or lower limbs, in conjunction with muscle strength or fatigue; (iii) level of ambulation; and (iv) respiratory function in adult SMA patients.

\subsection{General Mobility Tests}

The Hammersmith Functional Motor Scale Expanded (HFMSE) is a functional scale used for the assessment of physical abilities. It was adapted from the classic HFMS adding 13 new items that allow to capture a wider range of motor skills [26]. Therefore, the HFMSE has been proven to be a reliable indicator of the wide arrays of movements in adult SMA patients types 2 and 3 . In the effort to correlate the HFMSE score with the adult SMA types and subtypes, we collected the most recent available data on SMA types 2 and 3 (Table 2).

Independent studies exploring this aspect showed a consistent range of HFMSE score: between 0 and 20 for type 2 and between 25 and 66 for type 3 patients [27-29]. A larger range was recorded for the type 3 patients followed up by Walter and colleagues [18]. A similar trend, but with lower HFMSE score, for type $3 b$ patients (with symptoms onset after 3 years of age) has been described very 
recently by Kessler et al. [30]. Despite the variability for subtypes 3 and 3b, HFMSE seems to be a reliable indicator of the differences among SMA types.

Table 2. Summary of representative Hammersmith Functional Motor Scale Expanded (HFMSE) scores by SMA subtype. Graphical representation of the HFMSE scores in SMA patients from five independent studies. Columns are named as follows. References: bibliographic citations of the natural history or Nusinersen-related studies. Cohort: cohort composition in SMA patients with specified type or subtype when the information is available. T: time when the analysis was performed; 0 : baseline; +10 mo: 10 months after first Nusinersen dose. HMSFE: scores represented as a boxplot; values are indicated as median \pm standard deviation (s.d.). $\triangle$ HMFSE $\left(T-T_{0}\right)$ indicates the increment score between the baseline before treatment $\left(T_{0}\right)$ and the final after treatment timepoint $(T)$. N: number of patients included. Age: age of the subject in years as reported in the relative study (median (s.d.)). Colors of boxplot and dots are related to the cohort characteristics (SMA type): mustard: SMA type 2; green: type 3; light green: subtype $3 \mathrm{~b}$. Background color associates consecutive table entries referring to the same study.

\begin{tabular}{|c|c|c|c|c|c|}
\hline References & Cohort & $\mathrm{T}$ & HFMSE & $\mathbf{N}$ & Age \\
\hline Natural history studies & & & $\begin{array}{ccccccc}0 & 10 & 20 & 30 & 40 & 50 & 60 \\
\end{array}$ & & \\
\hline \multirow[t]{2}{*}{ Kaufmann et al. [27] } & type 2 & / & $\longmapsto 0$ & 41 & $9.1(7.4)$ \\
\hline & type 3 & / & 0 & 38 & $13.7(10.8)$ \\
\hline \multirow[t]{2}{*}{ Montes et al. [31] } & type 2 & / & $\longmapsto 0 \longrightarrow$ & 67 & $10.9(8.3)$ \\
\hline & type 3 & / & -1 & 59 & $13.4(10.7)$ \\
\hline Faravelli et al. [29] & type 3 & / & -1 & 12 & $29(15-35)$ \\
\hline Walter et al. [18] & type 3 & / & -1 & 19 & $29(15-35)$ \\
\hline Kessler et al. [30] & type $3 b$ & 0 & $\longmapsto$ & 7 & $39(13)$ \\
\hline \multirow{3}{*}{ Nusinersen-related studies } & & & $\Delta$ HFMSE $\left(T-T_{0}\right)$ & & \\
\hline & & & $\begin{array}{rrrrrrrr}-4 & -2 & 0 & 2 & 4 & 6 & 8 & 10 \\
\end{array}$ & & \\
\hline & type $3 b$ & +10 mo. & ! & 7 & $39(13)$ \\
\hline \multirow[t]{2}{*}{ Hagenacker et al. [19] } & type 2 & +10 mo. & rO- & 30 & \\
\hline & type 3 & +10 mo. & $\mapsto$ & 60 & $37(12)$ \\
\hline
\end{tabular}

Furthermore, this scoring system showed that there was a progressive gain during the course of the Nusinersen treatment, with an average gain of 3.12 points at 14 months after the first injection in 57 patients [19]. Results differed between SMA types 2 and 3, with a higher average HFMSE increase for SMA type 3 patients. Interestingly, no correlation was observed between the age at treatment and the evolution of the functional score during the treatment $[19,29]$.

\subsection{Revised Upper Limb Module}

The revised upper limb module (RULM) (see Table 3), a reconsidered version of the original upper limb module (ULM) [32], has been created to measure upper limb function in a wider range of patients [33] than the non-ambulatory young children and weaker patients [32]. The RULM includes 20 tasks based on a scale of 3 scores: 0 (unable), 1 (able, with modification), and 2 (able, no difficulty) [33]. A large natural history study across three countries analyzed the RULM score for 114 SMA type 2 and 3 patients, ranging from weak non-ambulant to stronger ambulant, over the course of 12 months [34]. This analysis confirms that the RULM scale can detect a wide spectrum of upper motor abilities even in ambulant patients where the ceiling effect was rarely reached $(11.4 \%$ of the cohort), overcoming the ULM scale limitations. Furthermore, it has been demonstrated that the RULM score is more useful than the HFMSE to picture motor differences in wheelchair-dependent adult SMA type 2 and 3 patients [35], suggesting that it can be used as diagnostic marker. Moreover, in patients treated with Nusinersen, RULM was shown to be more accurate than the HMFSE in detecting the improved motor abilities of type 2 and 3 patients (both young and adults) treated 
with Nusinersen $[18,19]$ at later time points (10-14 months after the first injection). All these data demonstrate that the RULM scale is a sensitive marker for both diagnostic and therapeutic monitoring purposes and it could be used in combination with a more general scale to reveal the finest motor differences for the large spectrum of adult patients.

Table 3. Summary of representative results for the Revised Upper Limb Module (RULM). Graphical representation of the RULM scores in SMA patients from three independent studies. Columns are named as follows. References: bibliographic citations of the natural history or Nusinersen-related studies. Cohort: cohort composition in SMA patients with specified type or subtype. T: time when the analysis was performed; 0: baseline; +10 mo: 10 months after first Nusinersen dose. RULM: scores represented as a boxplot; values are indicated as median $\pm \mathrm{sd}$. $\triangle \mathrm{RULM}\left(T-T_{0}\right)$ indicates the increment score between the baseline before treatment $\left(T_{0}\right)$ and the final after treatment timepoint $(\mathrm{T})$. $\mathbf{N}$ : number of patients included. Age: age of the subject in years as reported in the relative study (age range); NA: not available. Colors of boxplot and dots are related to the cohort characteristics (SMA type): mustard: SMA type 2; green: type 3. Background color associates consecutive table entries referring to the same study.

\begin{tabular}{|c|c|c|c|c|c|c|c|}
\hline References & Cohort & $\mathrm{T}$ & \multicolumn{4}{|c|}{ RULM } & Age \\
\hline \multirow{3}{*}{$\begin{array}{r}\text { Natural history studies } \\
\text { Stolte et al. [36] }\end{array}$} & & & $\stackrel{0}{+}$ & 10 & 20 & 30 & \\
\hline & type 2 & / & \multirow{2}{*}{\multicolumn{2}{|c|}{$\longmapsto$}} & \multirow{2}{*}{\multicolumn{2}{|c|}{$\longmapsto-1$}} & 4 to 48 \\
\hline & type 3 & 0 & & & & & 8 to 61 \\
\hline Walter et al. [18] & type 3 & 0 & & & \multicolumn{2}{|c|}{$\longmapsto-1$} & 8 to 59 \\
\hline \multirow{4}{*}{$\begin{array}{l}\text { Nusinersen-related study } \\
\text { Hagenacker et al. [19] }\end{array}$} & & & \multicolumn{4}{|c|}{$\Delta \operatorname{RULM}\left(T-T_{0}\right)$} & \\
\hline & & & 2 & 0 & , & & \\
\hline & type 2 & +10 mo. & \multicolumn{4}{|c|}{$\longmapsto 1$} & $N A$ \\
\hline & type 3 & +10 mo. & & $\frac{1}{1}$ & & & $N A$ \\
\hline
\end{tabular}

\subsection{Quantitative Assessment of Ambulation Capacity}

Among the five SMA types, only type 3 and 4 patients can walk unassisted. This is the highest milestone achievable by these patients; however, the probability of remaining ambulant decreases with aging. According to a study of natural history for type 3 SMA patients published by Zerres et al. [37], the probability of preserving ambulation throughout life is tightly linked to the age of disease onset. The authors showed that $83.7 \%$ of patients $(n=72)$ with symptomatic appearance between 18 and 35 months of age - corresponding to SMA type 3a-are able to walk 10 years after disease onset, and this percentage plummeted to $30 \%$ at 25 years after disease onset. Accordingly, among patients with a disease onset between 3 and 15 years old $(n=109)$-corresponding to SMA type $3 b$ subset—an average $95 \%$ were able to walk 10 years after disease onset and $75 \%$ at 25 years. These data clearly showed that the loss of the ability to walk declines slowly in patients with a later disease onset, suggesting that this outcome can be monitored to assess disease progression. Several functional scales have been exploited to strictly monitor the ability to walk, such as the 6-min walking test (6MWT).

The 6MWT is a functional test designed for ambulant patients, aiming to measure the distance that a patient can cover during a six-minute timelapse. The test can also document the gait pace by minute and indirectly describes motor fatigue over time. Guidelines for this test were published in 2002 by the American Thoracic Society (ATS) [38]. The 6MWT has been approved as an endpoint outcome in SMA patients motor function assessment [39]. As described in the ATS statement for the $6 \mathrm{MWT}$, individual factors might influence the outcome of the test, including sex, age, height, and weight, but also the personal motivation of the patient. For healthy subjects between 10 and 59 years of age, the 6MWT values range approximately from 600 to 850 meters (m) [40]. In SMA patients, the distance covered in 6 minutes is affected by both age and the type of SMA. Montes et al. [28] showed that the median value is generally higher for SMA subtype $3 b$ averaging at $368 \mathrm{~m}(\mathrm{n}=28)$ compared to $253 \mathrm{~m}$ for subtype 3a (see Table 4). However, the mean rate of progression in the two SMA subtypes 
did not differ significantly after 1 years from the baseline obervation. Moreover, one can notice the internal variability into each subtype and the important overlap between subtypes $3 \mathrm{a}$ and $3 \mathrm{~b}$.

The analysis of the ambulation is a valuable tool to follow up the response to treatment and few studies reported data obtained with the 6MWT. Recently, Hagenacker et al. [19] published the results of a multicenter, observational study on a cohort of 173 adult SMA patients treated with Nusinersen and followed up to 14 months. The 6MWT was used as a secondary endpoint for ambulant patients ( $\mathrm{n}=46$ at baseline; see Table 4). At all time points analyzed (6,10, and 14 months) patients showed a significant increase in the outcome of the 6MWT with an average gain of $22.1 \mathrm{~m}(8.7 \mathrm{~m}-35.6 \mathrm{~m}$; $95 \%$ Confidence Interval) after 6 months and 46 m (25.4 m-66.6 m; 95\% C.I.) after 14 months. Very interestingly, along the course of treatment, few non-ambulatory patients gained the ability to walk. This large cohort study provides evidence for the efficacy of Nusinersen treatment to improve the ambulatory function in adult SMA patients.

While the 6MWT gave some indications about treatment response in walking adult SMA patients, the variability in the degree of ambulation at both baseline and after treatment should be further explored and correlated to other functional and molecular parameters to better understand the disease.

Table 4. Summary of representative results for the 6-Minute-Walk-Test (6MWT) by ambulatory patients. Graphical representation of the $6 \mathrm{MWT}$ in healthy and SMA patients from four independent studies. Columns are named as follows. References: bibliographic citations of the natural history or Nusinersen-related studies. Cohort: cohort composition in healthy and/or SMA patients with specified type or subtype when the information is available. T: time when the analysis was performed. Distance: distance reported in meters and represented as a boxplot; values are indicated as median \pm standard deviation (s.d.). $\Delta$ Distance $\left(T-T_{0}\right)$ indicates increment distance covered between the baseline before treatment $\left(T_{0}\right)$ and the final after treatment timepoint $(\mathrm{T})$. $\mathrm{N}$ : number of patients included. Age: age of the subject in years as reported in the relative study (age range or mean (s.d.)); NA: not available. Colors of boxplot and dots are related to the cohort characteristics (SMA type or controls): gray: healthy subject; green: SMA type 3; dark green: SMA subtype 3a; light green: SMA subtype 3b. Background color associates consecutive table entries referring to the same study.

\begin{tabular}{|c|c|c|c|c|c|}
\hline References & Cohort & $\mathbf{T}$ & Distance (m) & $\mathbf{N}$ & Age \\
\hline \multirow{2}{*}{\multicolumn{6}{|c|}{ Natural history studies }} \\
\hline & & & & & 20 to 59 \\
\hline \multirow[t]{3}{*}{ Montes et al. [28] } & type $3 a$ & 0 & $\longmapsto$ & 57 & $10.3(9.8)$ \\
\hline & type $3 b$ & 0 & $\longmapsto$ & 28 & $25.6(12.5)$ \\
\hline & \multicolumn{5}{|c|}{$\Delta$ Distance $\left(T-T_{0}\right)$} \\
\hline \multirow[t]{2}{*}{ Montes et al. [28] } & type 3a & $+1 \mathrm{y}$ & r-! & 57 & $10.3(9.8)$ \\
\hline & type $3 b$ & $+1 \mathrm{y}$ & $\mapsto$ & 28 & $25.6(12.5)$ \\
\hline \multicolumn{6}{|l|}{ Nusinersen-related studies } \\
\hline \multirow[t]{3}{*}{ Hagenacker et al. [19] } & \multirow[t]{3}{*}{ type 3} & +6 mo. & \multirow{3}{*}{\begin{tabular}{lll}
$10-1$ \\
\hdashline 0
\end{tabular}} & 47 & $N A$ \\
\hline & & +10 mo. & & 37 & $N A$ \\
\hline & & +14 mo. & & 25 & $N A$ \\
\hline
\end{tabular}

\subsection{Lung Function Tests}

Respiratory function is impaired in SMA patients as the diaphragm and intercostal muscles are affected by the progression of the disease. The association of this alteration with recurrent scoliosis in patients can result in restrictive lung disease. Difficulty to cough can contribute to a reduced clearance and facilitate the onset of respiratory infections. This decline in the respiratory function is associated with mortality and morbidity in SMA patients of all types $[14,25]$. For this reason, many efforts have been devoted in the last few years to the search for appropriate parameters to assess this function. 
The natural history study of lung function in SMA patients, reported by Wijngaarde et al. [25], analyzed the Forced Expiratory Volume in 1 second $\left(\mathrm{FEV}_{1}\right)$ in a cohort of 170 patients SMA types $1 \mathrm{c}$ to 4 . Using these data, the authors were able to build age-dependent models of the evolution of this measure for 131 patients-subtypes $1 \mathrm{c}$ to $3 \mathrm{~b}$. The linear models obtained, as expected, showed a progressive annual decrease of the $\mathrm{FEV}_{1}$ from $100.35 \%$ predicted in newborns subtype $3 \mathrm{~b}$-almost normal lung function-to $42.12 \%$ in $1 \mathrm{c}$ newborns. They reported a $1.29 \%$ and $1.37 \%$ annual rate of decline for subtypes $2 a$ and $2 b$, respectively, which was associated with an early start of mechanical ventilation (median 12.3 and 16.8 years old, respectively). Subtypes 3a showed a milder $0.73 \%$ annual rate of decline, with a median age of 39.9 years old at start of mechanical ventilation. However, this analysis demonstrated that the average annual decline is dependent on age-faster decline in younger patients. Unfortunately, the effect of Nusinersen on the respiratory function in adult patients has been poorly studied so far. An encouraging 5\% increase in the average Force Volume Capacity (FVC) of the lungs has been recently reported in Walter et al. [18]. Further studies need to be performed to comprehensively evaluate the impact of Nusinersen treatment on SMA adult population and to define the appropriate outcome measures for lung functional evaluation.

\subsection{Additional Tests}

Together with the tests discussed above, a series of other functional measures have been widely used to assess the electrophysiological activity of motor neurons, the axon number and reinnervation potential, and the structural changes in spinal cord and muscles. For example, electromyography (EMG), compound muscle action potential (CMAP), and motor neuron number index (MUNIX) have been classically used in patients affected with neuromuscular disorders to assess the functional status of the motor unit [41-44]. The EMG and CMAP methods have been used for SMA diagnosis [43,45,46] and the CMAP has also been demonstrated to be a good prognostic marker [47]. The scarcity of available data on the use of EMG and CMAP for the adult patient population has discouraged the attribution of these tests as ideal outcomes for adult SMA patients at the moment.

Computed from CMAP and electromyography interference pattern, the MUNIX is a quantitative test that aims to estimate the number of functional motor units in a specific muscle [44]. Overall, MUNIX and MUSIX are very interesting tests for the assessment of the number and size of motor units, which have been demonstrated to be directly correlated with motor function in adult type 2 and 3 patients [48]. However, no data is currently available on the reliability of this test to capture adult patients' response to treatment (clinical trial NCT04139343 is currently recruiting patients to monitor MUNE in adults with SMA). Alterations in the cervical spinal cord of adult SMA patients have also been described due to a fine-tuned magnetic resonance imaging (MRI) [49] that can provide structural markers of the disease. Further refinement of the MRI techniques will certainly improve the sensitivity of the method [50] and apply it to a wider number of patients. It remains to be assessed whether it would be a reliable method to follow the response to treatments. Overall, the detailed evaluation of different functional outcomes gives insights regarding the disease progression. These efforts will contribute to a novel description of SMA patients, based on the classical definition of types and a more precise clinical assessment. However, observations made at the macro scale need to be complemented by molecular characterization in order to explain patient's variability and device powerful predictive models of disease progression.

\section{Genetic and Epigenetic Etiology of Clinical Heterogeneity}

The discordance between genotype and phenotype among patients with same genetic mutation and same SMN2 copy number can be explained by several factors, including (i) the presence of genetic modifiers and (ii) the epigenetic profile. These parameters need to be considered for both the natural history and to monitor the treatment response of SMA patients. 


\subsection{SMN2 and Other Genetic Modifiers}

Several genes have been identified in the last few years as SMA disease modifiers. These include Survival of Motor Neuron 2 (SMN2) [1,51], Plastin 3 (PLS3) [8], Coronin 1C (CORO1C) [9] and Neurocalcin Delta (NCALD) [10], Small EDRK-Rich Factor 1 (SERF1) [52], NLR Family Apoptosis Inhibitory Protein (NAIP) [53], General Transcription Factor IIH subunit 2 (i) [54], and Tolloid Like 2 (TLL2) [55]. Here, we will focus on the most documented genes.

The SMN2 gene is the main modifier gene in SMA. Only $10 \%$ of the mRNA transcribed from the SMN2 gene produces the functional FL-SMN protein. The number of copies of the SMN2 genes is directly correlated to the level of functional FL-SMN and affects the severity of the disease (see Figure 1B) [1,7,47,51,56-75].

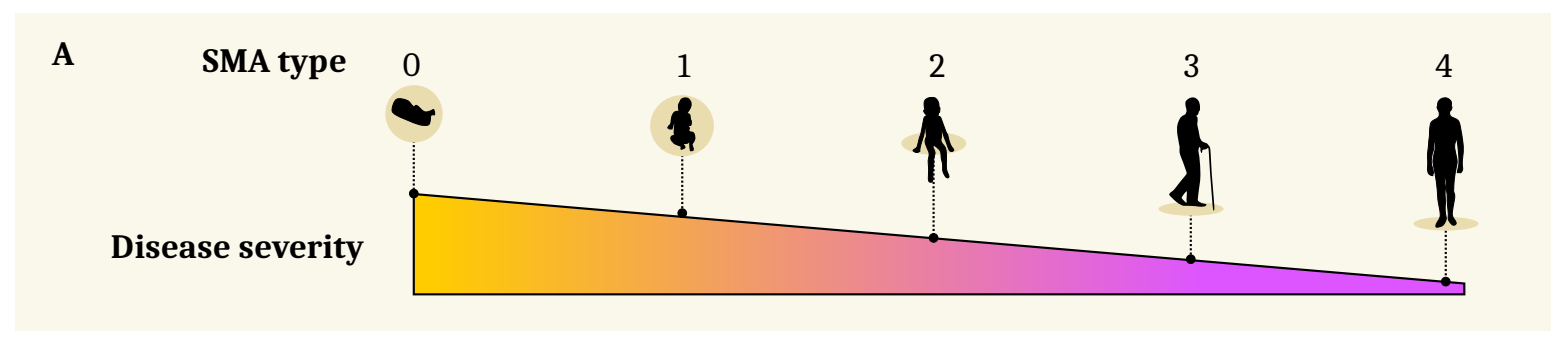

Disease modifiers

B SMN2

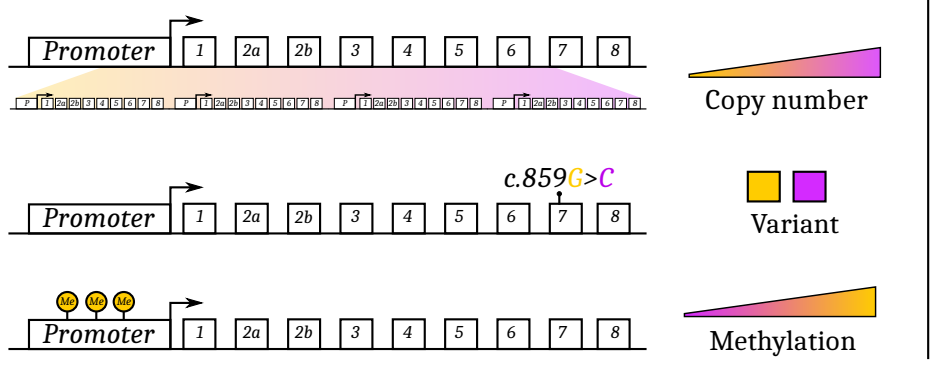

C Other modifier genes

Gene Expression

PLASTIN3

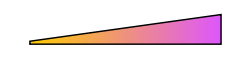

CORO1C

NCALD

Figure 1. Known molecular disease modifiers. (A) Current classification of SMA as a discrete projection of a continuous spectrum of disease severity. This spectrum results from the combination of (B) disease modifiers such as SMN2 copy number, SMN2 variant, and methylation state; (C) level of expression of CORO1C and PLASTIN3 was associated with milder phenotype, while NCALD overexpression was associated with more severe phenotype.

However, there are exceptions to this paradigm. Indeed, several type 2 and 3 SMA patients have been described to carry only two copies of SMN2 instead of the expected three or four copies. This phenotype is often due to a rare single nucleotide variant (SMN2 c.859G $>C$ ) in exon 7 that impacts SMN2 gene splicing [11,76-78], inducing a higher rate of production of the FL-SMN protein (Figure 1B). Moreover, research from several groups described a variability of clinical phenotypes in siblings carrying the same SMN1 mutation and identical SMN2 copy number [5,58,79-81]. These events suggested the presence of modifier factors other than the SMN2 gene are able to alter the severity of the disease and to be considered to define its full molecular signature.

\subsection{Plastin3}

F-actin bundling protein plastin 3 (PLS3) has been identified as the first gene, besides SMN2, to be able to attenuate the disease severity when upregulated (see Figure 1C). PLS3 encodes a $\mathrm{Ca}^{2+}$-dependent $\mathrm{F}$-actin-binding protein involved in neurotransmitter release and vesicle recycling at the presynaptic site [82]. The seminal work of Oprea et al. [8] demonstrated elevated levels of PLS3 in asymptomatic females of SMA type 2- or 3-affected sibling pairs where the males were 
always symptomatic. Each analyzed sibling pair carried identical homozygous SMN1 deletion and the same number of SMN2 copies. An additional study, described that the PLS3 higher expression is maintained after generation and differentiation of induced pluripotent stem cells from fibroblasts of asymptomatic but not symptomatic siblings [83]. Unfortunately, no association of PLS3 expression was found in discordant female sibling pairs in an Iranian population [84]. Highly divergent results have also been shown about the role of PLS3 in mouse models of SMA. While two independent studies described an amelioration of the SMA phenotype upon overexpression of PLS3 in mice [82,85], another report showed that a randomly integrated PLS3 allele expressed in the severely affected $\triangle 7$-SMA mouse model failed to show rescue of the mice survival or motor function [86]. These discrepancies can be attributed to the fact that PLS3 is directly regulated by the SMN protein [87]; therefore, its overexpression is effective only when used as an adjuvant treatment to the classic SMN induction therapy [9]. It is plausible that the expression of PLS3 is affected by the SMA currently administered therapies and it could be used as a putative molecular biomarker.

\subsection{PLS3-Interacting Protein CORO1C and CHP1}

As a PLS3 binding partner, CORO1C regulates synaptic vesicles recycling in a calcium-dependent manner [9]. When overexpressed, CORO1C induced a significant amount of F-actin, therefore ameliorating endocytosis at the neuromuscular junctions [9,86] (see Figure 1C). Recently identified using a yeast-two-hybrid screen, the calcineurin-like EF-hand protein 1 (CHP1) is a novel PLS3 interacting protein [88] upregulated in SMA mice. Treatment of SMA mice with a low dose of AS oligonucleotide-SMN combined with CHP1 downregulation improved the survival extension of the animals compared to the single SMN therapy [88]. The authors showed that the negative modulation of $C H P 1$ induced an activation of calcineurin with consequent restoration of endocytic protein phosphorylation. In the case where CORO1C and CHP1 are differentially expressed in SMA patients, their modulation could also be beneficial to improve therapeutic effects.

\subsection{NCALD}

NCALD is calcium sensor protein suggested to negatively impact SMA via repression of endocytosis [10]. Reduced expression of NCALD was shown to be protective in a four-generation discordant family with five asymptomatic and two SMA1-affected individuals [10]. Moreover, reducing NCALD levels either in vitro or in vivo significantly ameliorated SMA pathology across SMA species [10]. Based on these encouraging results, Torres-Benito et al. [89] developed an ASO-based therapy to target Ncald in mouse spinal cord and used it in combination with low-dose SMN splice switching ASOs to design an efficient combinatorial therapy in SMA mice [89]. Therefore, repression of NCALD is considered protective for SMA.

\subsection{NAIP}

Another gene located in the same chromosomic region (5q13) of SMN1 and -2 is NLR Family Apoptosis Inhibitory Protein (NAIP). The functional role of NAIP in the pathogenesis of SMA has not been fully elucidated. However, some reports have demonstrated a correlation between deletion of the NAIP gene and severity of SMA $[53,90]$ (see Figure 1). This gene was also found to be frequently deleted in $45 \%$ of the Egyptian patients [91]. Further investigation needs to be performed to validate the accuracy of this gene as a biomarker for SMA.

\subsection{Epigenetic Modifiers (Methylation)}

Epigenetic marks have been demonstrated to modulate the expression of the modifier genes in SMA. In particular, methylation in the promoter of the SMN2 gene was reported to reduce its transcription and consequently the expression of the SMN protein, independently of the SMN2 copy number (see Figure 1B). Studies on the methylation level of different CpGs on the SMN2 genes revealed that hypomethylation was associated with reduced disease severity [92]. In fact, 
SMA type 3 exhibited a lower degree of methylation in the SMN2 gene compared to type 1 or 2 patients [93]. After profiling the methylation in SMA patients and healthy controls, Zheleznyakova et al. identified differential degrees of methylation at CpG sites in the following genes; CHM Like Rab Escort Protein (CHML), Rho GTPase Activating Protein 22 (ARHGAP22), Cytokinesis And Spindle Organization B (CYTSB), Cyclin Dependent Kinase 2 Associated Protein 1 (CDK2AP1), and Solute Carrier Family 23 Member 2 (SLC23A2) [94]. Moreover, SLC23A2 was significantly hypomethylated in type 3 and 4 patients compared to type 1 [95]. Thus, DNA methylation may regulate the SMA disease phenotype by modulating gene transcription and could be the molecular mechanism beyond the genotype-phenotype discrepancy often observed in SMA. Whether these changes are induced by environmental factors variations [96] and whether they are dependent or not on the absence of SMN, remain open questions.

\subsection{Histone Deacetylases (HDAC) Inhibitors}

Many efforts have also been made to target the HDACs and impact the transcription of the SMN2 gene and its transduction into a functional SMN protein. Inhibition of HDACs impairs the removal of acetyl groups from the histone proteins and promotes gene transcription by mediating a more permissive, open, chromatin. In 2001, Chang et al. first identified an effect of a HDAC inhibitor, sodium butyrate, on SMA. Treatment with this epigenetic drug was able to increase the FL-SMN both in vitro and in vivo [97]. This discovery led to multiple investigations in the attempt to find more potent and stable HDAC inhibitors for SMA treatment. Valproic acid (VPA) [98,99], suberoylanilide hydroxamic acid (SAHA) [100,101], M344 [102], thricostatin A [103], and romidepsin [92] have also been suggested as promising treatments for SMA. The LBH589 molecule showed a higher potential than all other inhibitors, with the ability to induce a strong upregulation of SMN at very low doses [104]. Additionally, a combined therapy using the LBH589 inhibitor together with the Nusinersen drug showed a synergistic effect than the single treatments on SMA cellular models [105]. Despite the number of HDAC inhibitors tested and the encouraging results, only phenylbutyrate and VPA have entered clinical trials for human use. Valproic acid was tested in five Phase I/II clinical trials (NCT00374075, NCT00227266, NCT00481013, NCT00661453, and NCT01033331) [106-111] and showed outcomes variability. All the studies mentioned above were included in the meta-analysis performed by Elshafay et al. [112] suggesting the VPA administration was safe, although some adverse effects were recorded, and it induced a major improvement of motor function. The results of the SMA VALIANT trial (NCT00481013) on adult patients did not show any positive outcome on the motor function at either 6- or 12-month timepoints underlying that this treatment might have limited effects on the adult population [110]. A similar moderate success appeared from the pilot studies based on administration of phenylbutyrate to SMA patients [113-115]. More work needs to be done to establish whether these therapies could be used in combination with other approaches to efficiently ameliorate the SMA condition, even in the adults who seem less responsive to the currently approved therapies. The advantage of using HDAC inhibitors for SMA therapy, as other epigenetic drugs, is their ability to act on the chromatin without permanently affecting the DNA sequence. Moreover, some HDAC inhibitors have been demonstrated to reduce the methylation on the SMN2 promoter [92,101], therefore establishing a link between the two epigenetic modifications could be positively exploited in novel therapies.

\section{Molecular Biomarkers}

Biomarkers are needed in the field to provide the necessary insights to guide the decision-making in personalized medicine. There are several aspects to be considered in the identification of reliable biomarkers, like reproducibility and accuracy of measurements. We will discuss below the factors that have been identified as putative biomarkers for SMA. 


\subsection{SMN Protein}

The SMN protein is considered the biomarker of choice for SMA, as all the approved therapies are aimed to restore its expression. SMN is ubiquitously expressed [116] and regulates several key processes in neuronal cells including ribonucleoprotein assembly, RNA metabolism [117], actin cytoskeleton dynamics [118], mRNA transport [119], ubiquitin homeostasis [120], bioenergetics pathways [121], synaptic vesicle release [122], and local protein translation [123-125]. Therefore, SMN-reduced expression in SMA has a devastating impact on many aspects of the neuronal homeostasis and survival. In fact, MNs expressing lower amounts of the SMN protein are more vulnerable to cell death [12] and this contributes to disease variability. The goal of the approved therapies for SMA is to re-express SMN in the affected tissues, mainly in MNs, but the scenario has become more complex since multiple studies published in the last few years have reported the importance of re-expressing SMN in peripheral tissues in addition to the CNS [126,127]. However, little is known on the specific tissue requirement for SMN; only recently a study from Ramos et al. described a variable level of SMN expression in different tissues and a general decline with aging [128]. Moreover, no robust correlations between SMN2 copy number, and therefore SMA types, and SMN protein levels could have been demonstrated probably due to the tissue-specific SMN expression profile $[70,128,129]$. On the contrary, an analysis of SMN expression in spinal cord resident cells of treated patients revealed a higher amount of SMN protein in motor neurons after Nusinersen therapy [128]. These data suggest that SMN levels could serve as a potential biomarker to follow disease progression, although the reported discrepancies between SMN protein and mRNA expression $[128,129]$ warrant more investigation. Additionally, as mentioned above, the tissue-specific requirement for SMN and its correlation with the patient's response to treatment is largely unexplored and future research should address these problems to obtain a thorough follow-up, in particular for the adult SMA population.

\subsection{Neurofilaments}

Neurofilaments (NFs) are intermediate filaments of the neuronal axons, and they are abnormally released into the extracellular fluids, namely, CSF and peripheral blood, upon axonal damage in traumatic injuries or neurodegenerative disorders (reviewed in $[130,131])$. Constituted of three chains, light (NFl), medium (NF-M) and heavy (NF-H), based on their molecular weights, NFs are post-transcriptionally regulated [132]. In particular, the phosphorylation, abundant on the NF-H, ensures protection from degradation [133]. Although NFs seem to be reliable biomarkers for SMA infants, as their level is reduced upon Nusinersen treatment and this is generally correlated with an improved motor function [134], few recent publications have described contradicting results for the use of NFs as biomarkers for adult SMA patients' response to therapy [29,135]. Eleven SMA type 3 patients (all adults-38.5 years mean age) analyzed for their pNF-H content in blood and CSF showed no change after administration of the Nusinersen loading doses [136]. In agreement with this effect, no significant difference was observed in the amount of NfL and pNF-H in another group of SMA patients (types 2 and 3) after the fourth injection of Nusinersen [135]. On the other hand, outcomes of a recently published analysis on a cohort of SMA type 3 patients (including kids, adolescents, and adults) showed a significant reduced amount of NFl and pNF-H after three injections with Nusinersen [29]. These discrepancies could be due to the different duration of follow-up, six months in the latter study against two months post-treatment for the previous ones. Technical limitations might also significantly contribute to the divergent outcomes (e.g., different sensitivity of the ELISA kits used). It is to be noted that at the analyzed time points, despite a decrease in the NFs levels, no locomotor function amelioration was observed in adult patients, suggesting that this aspect should be examined to a greater extent. 


\subsection{Protein Tau}

Like neurofilaments, Tau is a neuron-specific structural protein, generally considered as a cortical neuronal marker. It was observed to be high in the CSF of patients with stroke [137], Alzheimer's disease [138] and Amyothrophic lateral sclerosis (ALS) [139]. In SMA children, the baseline level of Tau in the CSF was significantly higher than in controls and it decreased with Nusinersen treatment [140]. On the contrary, the eleven SMA type 3 patients also analyzed for the NF content, described above by Totzeck et al. [136], did not exhibit alteration in the amount of tau protein. The analyses of tau protein and the discordant outcomes highlight once again the importance of defining bigger cohorts of patients, in particular adults, to study putative molecular biomarkers for SMA.

\subsection{Serum Creatinine}

Most biomarker studies published to date for SMA are focusing on neuronal-related molecules as previously discussed. If neurofilament and tau levels can mirror neuronal death, it is also known that the skeletal muscle metabolism is altered in neuromuscular disorders, and this could be another aspect to investigate in the search for molecular biomarkers. Indeed, due to either progressive denervation and also to the autonomous reduced level of SMN [141,142], metabolic activity of muscles is impaired as the disease progresses. Few biomarkers of muscle activity are known such as creatinine, a waste product from the phosphorylation of adenosine diphosphate by creatine that mostly occurs in skeletal muscles. Levels of creatinine are relatively lower in patients with SMA than controls [143], as reported in a longitudinal study of a 238 SMA patient cohort. Indeed, in these SMA patients, creatinine levels correlated closely with maximum CMAP and MUNE values, even after correction for confounding factors such age and lean mass (muscle atrophy). These data suggest that serum creatinine could constitute an interesting biomarker of the muscle deterioration and, more generally, of the disease progression. However, the study failed to provide insights regarding the intra-type correlation of creatinine levels and MUNE or CMAP outcomes. A fundamental problem, especially for type 3 patients, is the wide range of phenotype and a very variable disease progression. Additionally, the range of variability from visit to visit, which is what would be needed to guide therapeutic strategies, seems to be very wide. Therefore, additional studies should be performed in clinical trials to explore if the therapies would affect the creatinine levels, and if so, whether these differences would be distinguishable from natural variations in patients.

\section{Strategies for the Discoveries of Novel Biomarkers Towards the Development of Personalized Medicine Approaches for SMA}

The quest for biomarkers in SMA is still ongoing. Monitoring neurofilaments levels seems to be a very promising biomarker for the prognosis of treated infant patients [134], but does not appear to constitute a robust biomarker for adults patients. Indeed, studies including only adults patients showed comparable values between SMA patients and controls (see results published in [29]), suggesting that the variability observed in SMA samples could be unrelated to the SMA pathogenesis. Consequently, no prognosis biomarker for the outcome of therapies in adult patients is known to date.

Here, we review the strategies that could help tackle this problem, highlighting the approaches used in recent papers and based on the advantages of the unbiased -omics toolbox (Table 5). We then discuss perspectives on the use of these novel techniques for the future development of personalized medicine for SMA. 


\subsection{Multi-Omics Approaches for the Identification of SMA Biomarkers and Potential Therapeutic Targets}

The first comprehensive -omics investigation of unprecedented scale and scope has been BforSMA (Biomarkers for SMA) [144]. The novelty of this study consisted on the use of several unbiased methods (metabolomics, proteomics, and transcriptomics) for the search of biomarkers in a large well-defined SMA patient cohort and age-matched healthy controls. Despite the identification of several putative biomarkers, further validation is needed to confirm these findings. The field is now widely relying on the use of unbiased approaches to highlight potential molecular candidates. Transcriptomic and proteomic approaches are our best hope to grasp the complex mechanism that shapes the landscape of SMA clinical heterogeneity. A genome-wide RNA sequencing analysis on MNs differentiated from patient-derived induced pluripotent stem cells (iPSC) revealed that endoplasmic reticulum stress is upregulated in SMA, representing a novel potential target pathway [145]. A similar transcriptomic analysis on iPSC has been used to identify enriched motifs in differentially expressed genes between SMA and control cells, and pinpoints synaptogamin binding cytoplasmic RNA interacting protein (SYNCRIP) as a key modulator of SMN [146].

Furthermore, an interesting strategy published by Nizzardo et al. [147] took advantage of the known pathophysiological processes in motor neuron disorders (MND) to perform a comprehensive transcriptomic analysis. In particular, the authors started from the observation that specific types of MNs are spared during the progression of the MND, like SMA and ALS. They then compared the transcriptomic profile of affected MNs of the brainstem and spinal cord with the rather unaffected ocular MNs in ALS [147]. This approach led to the identification of several differentially expressed genes (DEGs), including synaptotagmin, which was demonstrated to be a neuroprotective protein in ALS. These results, also confirmed in SMA patient-derived MNs, opened new avenues for the investigation of potential novel biomarkers for SMA. In an independent study, a proteomic approach has been used to screen for candidate proteins regulated by the Nusinersen treatment in a cohort of ten type 2 and 3 patients [30]. Different proteomic clusters were identified containing proteins that are differentially expressed before and after six Nusinersen injections. This analysis allowed the identification of neuronal and non-neuronal proteins that could not only be valuable biomarkers but they could also be putative targets of SMA combined therapies.

Table 5. Overview of multi-omics approaches used to date to characterize SMA and its progression.

References: bibliographic citations of the -omics studies. -Omics: Specific techniques employed in each study. Samples' source: biological material analyzed. Highlights: main insights on SMA pathogenesis gained in each study. Background colors are used to differentiate the cited studies.

\begin{tabular}{|c|c|c|c|}
\hline References & -Omics & Samples' Source & Highlights \\
\hline Finkel et al. [144] & $\begin{array}{l}\text { Metabolomic, } \\
\text { transcriptomic, } \\
\text { proteomic }\end{array}$ & $\begin{array}{l}\text { Plasma and urine from } 108 \\
\text { SMA patients type } 1,2 \text { and } 3 \\
\text { (between } 2 \text { and } 12 \text { years of age) }\end{array}$ & $\begin{array}{l}97 \text { proteins and } 59 \text { metabolites } \\
\text { in the plasma together with } \\
44 \text { metabolites in the urine } \\
\text { correlated with functional score }\end{array}$ \\
\hline Rizzo et al. [146] & Transcriptomic & $\begin{array}{l}\text { iPSCs-derived motorneurons } \\
\text { from SMA patients and healthy } \\
\text { controls }\end{array}$ & $\begin{array}{l}\text { NRXN2 protein downregulation } \\
\text { was identified as potentially } \\
\text { neuroprotective. }\end{array}$ \\
\hline Nizzardo et al. [147] & Transcriptomic & $\begin{array}{l}\text { Spinal and ocular } \\
\text { motoneurons isolated from } \\
\text { human central nervous system } \\
\text { sections from MND patients }\end{array}$ & $\begin{array}{l}\text { Synaptogamin } 13 \text { was identified } \\
\text { as a putative neuroprotective } \\
\text { protein in MND. }\end{array}$ \\
\hline Kessler et al. [30] & Proteomic & $\begin{array}{l}\text { CSF samples from } 10 \\
\text { Nusinersen-treated adults } \\
\text { SMA type } 2 \text { and } 3\end{array}$ & $\begin{array}{l}\text { No correlation between protein } \\
\text { profiling and functional score } \\
\text { evolution, over } 10 \text { months } \\
\text { treatment }\end{array}$ \\
\hline
\end{tabular}




\subsection{Perspectives for Personalized Medicine in Neuromuscular Disorders}

Successful examples of personalized medicine approaches relying on multi-omics tools come from the cancer field. Indeed, a great effort in the last decade was focused in designing targeted therapies based on cancer mutation profiles [148]. The combination of molecular screening and analysis of predictive biomarkers represents a successful emerging strategy for cancer treatment [148]. Similarly, for high-burden bacterial infections, next-generation sequencing (NGS) of the patient's fluids will surely revolutionize the diagnostic process. The pathogen can be easily identified thanks to available bioinformatic data analyzed via artificial intelligence (AI) workflows and, consequently, the appropriate therapy can be quickly determined $[149,150]$. For SMA and other neuromuscular disorders, these approaches could ideally lead to personalized therapies but major hurdles need to be overcome. First, for these diseases the affected tissues are not readily available for biopsy and, second, the disease spectrum is highly complex, as thoroughly discussed above [151]. Thus, further endeavors are necessary to define personalized medicine approaches for the broad SMA population.

\section{Conclusions and Discussion}

The complexity of the SMA phenotypes, and the discrepancies between patients' genotype (as per current definition) and phenotype, have fostered the search for functional and molecular biomarkers that could help to better classify patient types. The discovery of several disease modifier genes, starting with SMN2 [1], and epigenetic factors [92] has revolutionized the traditional classification and account for a wider complexity. This aspect will further change in light of the recently approved therapies that are modifying the course of the disease and increasing patients' survival. For the functional measurements, it is now clear that the available tests to date are inappropriate to grasp the small changes in locomotor abilities or electrophysiological parameters of adult SMA patients. In fact, these changes seem to fall into a different scale compared to the ones form younger patients that have been widely investigated. Therefore, refining the existing scales and finding novel functional measures is a priority [152]. On the other hand, many efforts have been devoted to the identification of reliable molecular biomarkers but all the proposed candidates have revealed some limitations. Therefore, novel screening methods, approaches for an accurate prognosis, and biomarkers for treatment follow-up are being identified. Recent technological advances have allowed the development of many tools that will considerably improve the extent of the analysis. For example, novel sensitive techniques such as NGS can currently identify a broader range of genetic and epigenetic differences that can be explored as possible biomarkers. Therefore, further investigation needs to be performed to unbiasedly identify putative biomarkers for accurate diagnosis, prognosis, and treatment monitoring in SMA. These efforts, combined with refined AI approaches, will represent a milestone for a successful personalized medicine development in SMA.

Author Contributions: Conceptualization, M.G.B and P.S.; writing-original draft preparation, P.S. and P.L.; writing-review and editing, M.G.B. and P.S.; preparation of tables and figure, P.L.; revision, G.Q.; funding acquisition, M.G.B. and P.S. All authors have read and agreed to the published version of the manuscript.

Funding: This research was funded by the Association Française contre les Myopathies (AFM) and the Association Institut de Myologie (AIM), the Sorbonne Université, and the Institut National de la Santé et de la Recherche Médicale (INSERM). P.S. received funding from the Marie Skłodowska-Curie Actions under grant agreement No. 896715.

Conflicts of Interest: The authors declare no conflicts of interest.

\section{References}

1. Lefebvre, S.; Bürglen, L.; Reboullet, S.; Clermont, O.; Burlet, P.; Viollet, L.; Benichou, B.; Cruaud, C.; Millasseau, P.; Zeviani, M.; et al. Identification and characterization of a spinal muscular atrophy-determining gene. Cell 1995, 80, 155-165. [CrossRef]

2. Prior, T.W. Perspectives and diagnostic considerations in spinal muscular atrophy. Genet. Med. 2010, 12, 145-152. [CrossRef] 
3. Maretina, M.A.; Zheleznyakova, G.Y.; Lanko, K.M.; Egorova, A.A.; Baranov, V.S.; Kiselev, A.V. Molecular factors involved in spinal muscular atrophy pathways as possible disease-modifying candidates. Curr. Genom. 2018, 19, 339-355. [CrossRef] [PubMed]

4. Lunn, M.R.; Wang, C.H. Spinal muscular atrophy. Lancet 2008. doi:10.1016/S0140-6736(08)60921-6. [CrossRef]

5. Cuscó, I.; Barceló, M.; Rojas-García, R.; Illa, I.; Gamez, J.; Cervera, C.; Pou, A.; Izquierdo, G.; Baiget, M.; Tizzano, E. SMN2 copy number predicts acute or chronic spinal muscular atrophy but does not account for intrafamilial variability in siblings. J. Neurol. 2006, 253, 21-25. [CrossRef]

6. Jones, C.C.; Cook, S.F.; Jarecki, J.; Belter, L.; Reyna, S.P.; Staropoli, J.; Farwell, W.; Hobby, K. Spinal Muscular Atrophy (SMA) Subtype Concordance in Siblings: Findings From the Cure SMA Cohort. J. Neuromuscul. Dis. 2020, 7, 33-40. [CrossRef]

7. Feldkötter, M.; Schwarzer, V.; Wirth, R.; Wienker, T.F.; Wirth, B. Quantitative analyses of SMN1 and SMN2 based on real-time lightCycler PCR: Fast and highly reliable carrier testing and prediction of severity of spinal muscular atrophy. Am. J. Hum. Genet. 2002, 70, 358-368. [CrossRef]

8. Oprea, G.E.; Kröber, S.; McWhorter, M.L.; Rossoll, W.; Müller, S.; Krawczak, M.; Bassell, G.J.; Beattie, C.E.; Wirth, B. Plastin 3 is a protective modifier of autosomal recessive spinal muscular atrophy. Science 2008, 320, 524-527. [CrossRef]

9. Hosseinibarkooie, S.; Peters, M.; Torres-Benito, L.; Rastetter, R.H.; Hupperich, K.; Hoffmann, A.; Mendoza-Ferreira, N.; Kaczmarek, A.; Janzen, E.; Milbradt, J.; et al. The power of human protective modifiers: PLS3 and CORO1C unravel impaired endocytosis in spinal muscular atrophy and rescue SMA phenotype. Am. J. Hum. Genet. 2016, 99, 647-665. [CrossRef]

10. Riessland, M.; Kaczmarek, A.; Schneider, S.; Swoboda, K.J.; Löhr, H.; Bradler, C.; Grysko, V.; Dimitriadi, M.; Hosseinibarkooie, S.; Torres-Benito, L.; et al. Neurocalcin delta suppression protects against spinal muscular atrophy in humans and across species by restoring impaired endocytosis. Am. J. Hum. Genet. 2017, 100, 297-315. [CrossRef]

11. Calucho, M.; Bernal, S.; Alías, L.; March, F.; Venceslá, A.; Rodríguez-Álvarez, F.J.; Aller, E.; Fernández, R.M.; Borrego, S.; Millán, J.M.; et al. Correlation between SMA type and SMN2 copy number revisited: An analysis of 625 unrelated Spanish patients and a compilation of 2834 reported cases. Neuromuscul. Disord. 2018, 28, 208-215. [CrossRef] [PubMed]

12. Rodriguez-Muela, N.; Litterman, N.K.; Norabuena, E.M.; Mull, J.L.; Galazo, M.J.; Sun, C.; Ng, S.Y.; Makhortova, N.R.; White, A.; Lynes, M.M.; et al. Single-cell analysis of SMN reveals its broader role in neuromuscular disease. Cell Rep. 2017, 18, 1484-1498. [CrossRef] [PubMed]

13. Tu, W.Y.; Simpson, J.E.; Highley, J.R.; Heath, P.R. Spinal muscular atrophy: Factors that modulate motor neurone vulnerability. Neurobiol. Dis. 2017, 102, 11-20. [CrossRef] [PubMed]

14. Finkel, R.S.; Mercuri, E.; Darras, B.T.; Connolly, A.M.; Kuntz, N.L.; Kirschner, J.; Chiriboga, C.A.; Saito, K.; Servais, L.; Tizzano, E.; et al. Nusinersen versus sham control in infantile-onset spinal muscular atrophy. N. Engl. J. Med. 2017, 377, 1723-1732. [CrossRef]

15. Chiriboga, C.A.; Swoboda, K.J.; Darras, B.T.; Iannaccone, S.T.; Montes, J.; Darryl, C.; Norris, D.A.; Bennett, C.F.; Bishop, K.M. Results from a phase 1 study of nusinersen (ISIS-SMNRx) in children with spinal muscular atrophy. Neurology 2016, 86, 890-897. [CrossRef]

16. Ratni, H.; Ebeling, M.; Baird, J.; Bendels, S.; Bylund, J.; Chen, K.S.; Denk, N.; Feng, Z.; Green, L.; Guerard, M.; et al. Discovery of risdiplam, a selective survival of motor neuron-2 (SMN2) gene splicing modifier for the treatment of spinal muscular atrophy (SMA). J. Med. Chem. 2018, 61, 6501-6517.

17. Mendell, J.R.; Al-Zaidy, S.; Shell, R.; Arnold, W.D.; Rodino-Klapac, L.R.; Prior, T.W.; Lowes, L.; Alfano, L.; Berry, K.; Church, K.; et al. Single-dose gene-replacement therapy for spinal muscular atrophy. N. Engl. J. Med. 2017, 377, 1713-1722. [CrossRef]

18. Walter, M.C.; Wenninger, S.; Thiele, S.; Stauber, J.; Hiebeler, M.; Greckl, E.; Stahl, K.; Pechmann, A.; Lochmüller, H.; Kirschner, J.; et al. Safety and treatment effects of nusinersen in longstanding adult 5q-SMA type 3-A prospective observational study. J. Neuromuscul. Dis. 2019, 6, 453-465. doi:10.3233/JND-190416. [CrossRef] 
19. Hagenacker, T.; Wurster, C.D.; Günther, R.; Schreiber-Katz, O.; Osmanovic, A.; Petri, S.; Weiler, M.; Ziegler, A.; Kuttler, J.; Koch, J.C.; et al. Nusinersen in adults with 5q spinal muscular atrophy: A non-interventional, multicentre, observational cohort study. Lancet Neurol. 2020, 19, 317-325. doi:10.1016/S1474-4422(20)30037-5. [CrossRef]

20. Jochmann, E.; Steinbach, R.; Jochmann, T.; Chung, H.Y.; Rödiger, A.; Neumann, R.; Mayer, T.E.; Kirchhof, K.; Loudovici-Krug, D.; Smolenski, U.C.; et al. Experiences from treating seven adult $5 \mathrm{q}$ spinal muscular atrophy patients with Nusinersen. Ther. Adv. Neurol. Disord. 2020, 13, 1756286420907803. [CrossRef] [PubMed]

21. Deymeer, F.; Serdaroglu, P.; Parman, Y.; Poda, M. Natural history of SMA IIIb: Muscle strength decreases in a predictable sequence and magnitude. Neurology 2008, 71, 644-649. [CrossRef] [PubMed]

22. Tiziano, F.D.; Lomastro, R.; Di Pietro, L.; Pasanisi, M.B.; Fiori, S.; Angelozzi, C.; Abiusi, E.; Angelini, C.; Soraru, G.; Gaiani, A.; et al. Clinical and molecular cross-sectional study of a cohort of adult type III spinal muscular atrophy patients: Clues from a biomarker study. Eur. J. Hum. Genet. 2013, 21, 630-636. [CrossRef] [PubMed]

23. Kariyawasam, D.S.; D'silva, A.; Lin, C.; Ryan, M.M.; Farrar, M.A. Biomarkers and the development of a personalized medicine approach in spinal muscular atrophy. Front. Neurol. 2019, 10, 1-12. doi:10.3389/fneur.2019.00898. [CrossRef] [PubMed]

24. Wadman, R.; Wijngaarde, C.; Stam, M.; Bartels, B.; Otto, L.; Lemmink, H.; Schoenmakers, M.; Cuppen, I.; van den Berg, L.; van der Pol, W. Muscle strength and motor function throughout life in a cross-sectional cohort of 180 patients with spinal muscular atrophy types 1c-4. Eur. J. Neurol. 2018, 25, 512-518. [CrossRef]

25. Wijngaarde, C.A.; Veldhoen, E.S.; van Eijk, R.P.; Stam, M.; Otto, L.A.; Asselman, F.L.; Wösten-van Asperen, R.M.; Hulzebos, E.H.; Verweij-van den Oudenrijn, L.P.; Bartels, B.; et al. Natural history of lung function in spinal muscular atrophy. Orphanet J. Rare Dis. 2020, 15, 1-11. [CrossRef]

26. O'Hagen, J.M.; Glanzman, A.M.; McDermott, M.P.; Ryan, P.A.; Flickinger, J.; Quigley, J.; Riley, S.; Sanborn, E.; Irvine, C.; Martens, W.B.; et al. An expanded version of the Hammersmith Functional Motor Scale for SMA II and III patients. Neuromuscul. Disord. 2007, 17, 693-697. [CrossRef]

27. Kaufmann, P.; McDermott, M.P.; Darras, B.T.; Finkel, R.S.; Sproule, D.M.; Kang, P.B.; Oskoui, M.; Constantinescu, A.; Gooch, C.L.; Foley, A.R.; et al. Prospective cohort study of spinal muscular atrophy types 2 and 3. Neurology 2012, 79, 1889-1897. [CrossRef]

28. Montes, J.; McDermott, M.P.; Mirek, E.; Mazzone, E.S.; Main, M.; Glanzman, A.M.; Duong, T.; Young, S.D.; Salazar, R.; Pasternak, A.; et al. Ambulatory function in spinal muscular atrophy: Age-related patterns of progression. PLoS ONE 2018, 13, e0199657. [CrossRef]

29. Faravelli, I.; Meneri, M.; Saccomanno, D.; Velardo, D.; Abati, E.; Gagliardi, D.; Parente, V.; Petrozzi, L.; Ronchi, D.; Stocchetti, N.; et al. Nusinersen treatment and cerebrospinal fluid neurofilaments: An explorative study on Spinal Muscular Atrophy type 3 patients. J. Cell. Mol. Med. 2020, 1-6. doi:10.1111/jcmm.14939. [CrossRef]

30. Kessler, T.; Latzer, P.; Schmid, D.; Warnken, U.; Saffari, A.; Ziegler, A.; Kollmer, J.; Möhlenbruch, M.; Ulfert, C.; Herweh, C.; et al. Cerebrospinal fluid proteomic profiling in nusinersen-treated patients with spinal muscular atrophy. J. Neurochem. 2020, e14953. doi:10.1111/jnc.14953. [CrossRef]

31. Montes, J.; Glanzman, A.M.; Mazzone, E.S.; Martens, W.B.; Dunaway, S.; Pasternak, A.; Riley, S.O.; Quigley, J.; Pandya, S.; De Vivo, D.C.; et al. Spinal muscular atrophy functional composite score: A functional measure in spinal muscular atrophy. Muscle Nerve 2015, 52, 942-947. [CrossRef] [PubMed]

32. Mazzone, E.; Bianco, F.; Martinelli, D.; Glanzman, A.M.; Messina, S.; De Sanctis, R.; Main, M.; Eagle, M.; Florence, J.; Krosschell, K.; et al. Assessing upper limb function in nonambulant SMA patients: Development of a new module. Neuromuscul. Disord. 2011, 21, 406-412. [CrossRef]

33. Mazzone, E.S.; Mayhew, A.; Montes, J.; Ramsey, D.; Fanelli, L.; Young, S.D.; Salazar, R.; De Sanctis, R.; Pasternak, A.; Glanzman, A.; et al. Revised upper limb module for spinal muscular atrophy: Development of a new module. Muscle Nerve 2017, 55, 869-874. [CrossRef] [PubMed]

34. Pera, M.C.; Coratti, G.; Mazzone, E.S.; Montes, J.; Scoto, M.; De Sanctis, R.; Main, M.; Mayhew, A.; Muni Lofra, R.; Dunaway Young, S.; et al. Revised upper limb module for spinal muscular atrophy: 12 month changes. Muscle Nerve 2019, 59, 426-430. [CrossRef] [PubMed] 
35. Kizina, K.; Stolte, B.; Totzeck, A.; Bolz, S.; Fleischer, M.; Mönninghoff, C.; Guberina, N.; Oldenburg, D.; Forsting, M.; Kleinschnitz, C.; et al. Clinical implication of dosimetry of computed tomography-and fluoroscopy-guided intrathecal therapy with nusinersen in adult patients with spinal muscular atrophy. Front. Neurol. 2019, 10, 1166. [CrossRef]

36. Stolte, B.; Totzeck, A.; Kizina, K.; Bolz, S.; Pietruck, L.; Mönninghoff, C.; Guberina, N.; Oldenburg, D.; Forsting, M.; Kleinschnitz, C.; et al. Feasibility and safety of intrathecal treatment with nusinersen in adult patients with spinal muscular atrophy. Ther. Adv. Neurol. Disord. 2018, 11, 1756286418803246. [CrossRef]

37. Zerres, K.; Rudnik-Schöneborn, S.; Forrest, E.; Lusakowska, A.; Borkowska, J.; Hausmanowa-Petrusewicz, I. A collaborative study on the natural history of childhood and juvenile onset proximal spinal muscular atrophy (type II and III SMA): 569 patients. J. Neurol. Sci. 1997, 146, 67-72. [CrossRef]

38. ATS statement: Guidelines for the six-minute walk test. Am. J. Respir. Crit. Care Med. 2002, 166, 111-117. [CrossRef]

39. Dunaway Young, S.; Montes, J.; Kramer, S.S.; Marra, J.; Salazar, R.; Cruz, R.; Chiriboga, C.A.; Garber, C.E.; De Vivo, D.C. Six-minute walk test is reliable and valid in spinal muscular atrophy. Muscle Nerve 2016, 54, 836-842. [CrossRef]

40. McKay, M.J.; Baldwin, J.N.; Ferreira, P.; Simic, M.; Vanicek, N.; Burns, J.; For the 1000 Norms Project Consortium. Reference values for developing responsive functional outcome measures across the lifespan. Neurology 2017, 88, 1512-1519. [CrossRef]

41. Mills, K.R. The basics of electromyography. J. Neurol. Neurosurg. Psychiatry 2005, 76, ii32-ii35. [CrossRef] [PubMed]

42. Kimura, J. Peripheral nerve conduction studies and neuromuscular junction testing. In Handbook of Clinical Neurophysiology; Elsevier: Amsterdam, The Netherlands, 2004; Volume 4, pp. 241-270.

43. Arnold, W.D.; Porensky, P.N.; McGovern, V.L.; Iyer, C.C.; Duque, S.; Li, X.; Meyer, K.; Schmelzer, L.; Kaspar, B.K.; Kolb, S.J.; et al. Electrophysiological biomarkers in spinal muscular atrophy: Proof of concept. Ann. Clin. Transl. Neurol. 2014, 1, 34. [CrossRef] [PubMed]

44. Nandedkar, S.D.; Nandedkar, D.S.; Barkhaus, P.E.; Stalberg, E.V. Motor unit number index (MUNIX). IEEE Tans. Biomed. Eng. 2004, 51, 2209-2211. [CrossRef] [PubMed]

45. Hausmanowa-Petrusewicz, I. Role of electromyography in the diagnosis of motor neuron disorders. Neuropatol. Pol. 1992, 30, 187-197.

46. Kolb, S.J.; Coffey, C.S.; Yankey, J.W.; Krosschell, K.; Arnold, W.D.; Rutkove, S.B.; Swoboda, K.J.; Reyna, S.P.; Sakonju, A.; Darras, B.T.; et al. Natural history of infantile-onset spinal muscular atrophy. Ann. Neurol. 2017, 82, 883-891. [CrossRef]

47. Swoboda, K.J.; Prior, T.W.; Scott, C.B.; McNaught, T.P.; Wride, M.C.; Reyna, S.P.; Bromberg, M.B. Natural history of denervation in SMA: Relation to age, SMN2 copy number, and function. Ann. Neurol. Offi. J. Am. Neurol. Assoc. Child Neurol. Soc. 2005, 57, 704-712. [CrossRef]

48. Querin, G.; Lenglet, T.; Debs, R.; Stojkovic, T.; Béhin, A.; Salachas, F.; Le Forestier, N.; del Mar Amador, M.; Lacomblez, L.; Meininger, V.; et al. The motor unit number index (MUNIX) profile of patients with adult spinal muscular atrophy. Clini. Neurophysiol. 2018, 129, 2333-2340. [CrossRef]

49. Querin, G.; El Mendili, M.M.; Lenglet, T.; Behin, A.; Stojkovic, T.; Salachas, F.; Devos, D.; Le Forestier, N.; del Mar Amador, M.; Debs, R.; et al. The spinal and cerebral profile of adult spinal-muscular atrophy: A multimodal imaging study. NeuroImage Clin. 2019, 21, 101618. [CrossRef]

50. Taso, M.; Le Troter, A.; Sdika, M.; Ranjeva, J.P.; Guye, M.; Bernard, M.; Callot, V. Construction of an in vivo human spinal cord atlas based on high-resolution MR images at cervical and thoracic levels: Preliminary results. Magn. Reson. Mater. Phys. Biol. Med. 2014, 27, 257-267. [CrossRef]

51. Lefebvre, S.; Burlet, P.; Liu, Q.; Bertrandy, S.; Clermont, O.; Munnich, A.; Dreyfuss, G.; Melki, J. Correlation between severity and SMN protein level in spinal muscular atrophy. Nat. Genet. 1997, 16, 265-269. [CrossRef]

52. Scharf, J.M.; Endrizzi, M.G.; Wetter, A.; Huang, S.; Thompson, T.G.; Zerres, K.; Dietrich, W.F.; Wirth, B.; Kunkel, L.M. Identification of a candidate modifying gene for spinal muscular atrophy by comparative genomics. Nat. Genet. 1998, 20, 83-86. [CrossRef] [PubMed]

53. Anderson, K.; Talbot, K. Spinal muscular atrophies reveal motor neuron vulnerability to defects in ribonucleoprotein handling. Curr. Opin. Neurol. 2003, 16, 595-599. [CrossRef] [PubMed] 
54. Bürglen, L.; Seroz, T.; Miniou, P.; Lefebvre, S.; Burlet, P.; Munnich, A.; Pequignot, E.V.; Egly, J.M.; Melki, J. The gene encoding $\mathrm{p} 44$, a subunit of the transcription factor TFIIH, is involved in large-scale deletions associated with Werdnig-Hoffmann disease. Am. J. Hum. Genet. 1997, 60, 72. [PubMed]

55. Jiang, J.; Huang, J.; Gu, J.; Cai, X.; Zhao, H.; Lu, H. Genomic analysis of a spinal muscular atrophy (SMA) discordant family identifies a novel mutation in TLL2, an activator of growth differentiation factor 8 (myostatin): A case report. BMC Med. Genet. 2019, 20, 204. [CrossRef]

56. Van der Steege, G.; Grootscholten, P.; Van der Vlies, P.; Draaijers, T.; Osinga, J.; Cobben, J.; Scheffer, H.; Buys, C. PCR-based DNA test to confirm clinical diagnosis of autosomal recessive spinal muscular atrophy. Lancet 1995, 345, 985-986. [CrossRef]

57. Coovert, D.D.; Le, T.T.; McAndrew, P.E.; Strasswimmer, J.; Crawford, T.O.; Mendell, J.R.; Coulson, S.E.; Androphy, E.J.; Prior, T.W.; Burghes, A.H. The survival motor neuron protein in spinal muscular atrophy. Hum. Mol. Genet. 1997, 6, 1205-1214. [CrossRef]

58. McAndrew, P.; Parsons, D.; Simard, L.; Rochette, C.; Ray, P.; Mendell, J.; Prior, T.; Burghes, A. Identification of proximal spinal muscular atrophy carriers and patients by analysis of SMNT and SMNC gene copy number. Am. J. Hum. Genet. 1997, 60, 1411-1422. [CrossRef]

59. Taylor, J.E.; Thomas, N.H.; Lewis, C.M.; Abbs, S.J.; Rodrigues, N.R.; Davies, K.E.; Mathew, C.G. Correlation of SMN t and SMN c gene copy number with age of onset and survival in spinal muscular atrophy. Eur. J. Hum. Genet. 1998, 6, 467-474. [CrossRef]

60. Mailman, M.D.; Heinz, J.W.; Papp, A.C.; Snyder, P.J.; Sedra, M.S.; Wirth, B.; Burghes, A.H.; Prior, T.W. Molecular analysis of spinal muscular atrophy and modification of the phenotype by SMN2. Genet. Med. 2002, 4, 20-26. [CrossRef]

61. Anhuf, D.; Eggermann, T.; Rudnik-Schöneborn, S.; Zerres, K. Determination of SMN1 and SMN2 copy number using TaqMan ${ }^{\mathrm{TM}}$ technology. Hum. Mutat. 2003, 22, 74-78. [CrossRef]

62. Scarciolla, O.; Stuppia, L.; De Angelis, M.V.; Murru, S.; Palka, C.; Giuliani, R.; Pace, M.; Di Muzio, A.; Torrente, I.; Morella, A.; et al. Spinal muscular atrophy genotyping by gene dosage using multiple ligation-dependent probe amplification. Neurogenetics 2006, 7, 269-276. [CrossRef] [PubMed]

63. Wirth, B.; Brichta, L.; Schrank, B.; Lochmüller, H.; Blick, S.; Baasner, A.; Heller, R. Mildly affected patients with spinal muscular atrophy are partially protected by an increased SMN2 copy number. Hum. Genet. 2006, 119, 422-428. [CrossRef] [PubMed]

64. Gómez-Curet, I.; Robinson, K.G.; Funanage, V.L.; Crawford, T.O.; Scavina, M.; Wang, W. Robust quantification of the SMN gene copy number by real-time TaqMan PCR. Neurogenetics 2007, 8, 271-278. [CrossRef] [PubMed]

65. Huang, C.H.; Chang, Y.Y.; Chen, C.H.; Kuo, Y.S.; Hwu, W.L.; Gerdes, T.; Ko, T.M. Copy number analysis of survival motor neuron genes by multiplex ligation-dependent probe amplification. Genet. Med. 2007, 9, 241-248. [CrossRef]

66. Tiziano, F.; Bertini, E.; Messina, S.; Angelozzi, C.; Pane, M.; D'Amico, A.; Alfieri, P.; Fiori, S.; Battini, R.; Berardinelli, A.; et al. The Hammersmith functional score correlates with the SMN2 copy number: A multicentric study. Neuromuscul. Disord. 2007, 17, 400-403. [CrossRef]

67. Elsheikh, B.; Prior, T.; Zhang, X.; Miller, R.; Kolb, S.J.; Moore, D.; Bradley, W.; Barohn, R.; Bryan, W.; Gelinas, D.; et al. An analysis of disease severity based on SMN2 copy number in adults with spinal muscular atrophy. Muscle Nerve Off. J. Am. Assoc. Electrodiagn. Med. 2009, 40, 652-656. [CrossRef]

68. Alias, L.; Bernal, S.; Barceló, M.J.; Also-Rallo, E.; Martínez-Hernández, R.; Rodriguez-Alvarez, F.J.; Hernández-Chico, C.; Baiget, M.; Tizzano, E.F. Accuracy of marker analysis, quantitative real-time polymerase chain reaction, and multiple ligation-dependent probe amplification to determine SMN2 copy number in patients with spinal muscular atrophy. Genet. Test. Mol. Biomark. 2011, 15, 587-594. [CrossRef]

69. Amara, A.; Adala, L.; Charfeddine, I.B.; Mamaï, O.; Mili, A.; Lazreg, T.B.; H'mida, D.; Amri, F.; Salem, N.; Boughammura, L.; et al. Correlation of SMN2, NAIP, p44, H4F5 and Occludin genes copy number with spinal muscular atrophy phenotype in Tunisian patients. Eur. J. Paediatric Neurol. 2012, 16, 167-174. [CrossRef]

70. Crawford, T.O.; Paushkin, S.V.; Kobayashi, D.T.; Forrest, S.J.; Joyce, C.L.; Finkel, R.S.; Kaufmann, P.; Swoboda, K.J.; Tiziano, D.; Lomastro, R.; et al. Evaluation of SMN protein, transcript, and copy number in the biomarkers for spinal muscular atrophy (BforSMA) clinical study. PLoS ONE 2012, 7 e33572. [CrossRef] 
71. Dobrowolski, S.F.; Pham, H.T.; Pouch Downes, F.; Prior, T.W.; Naylor, E.W.; Swoboda, K.J. Newborn screening for spinal muscular atrophy by calibrated short-amplicon melt profiling. Clin. Chem. 2012, 58, 1033-1039. [CrossRef]

72. Kirwin, S.M.; Vinette, K.M.; Gonzalez, I.L.; Abdulwahed, H.A.; Al-Sannaa, N.; Funanage, V.L. A homozygous double mutation in SMN 1: A complicated genetic diagnosis of SMA. Mol. Genet. Genom. Med. 2013, 1, 113-117. [CrossRef] [PubMed]

73. Brkušanin, M.; Kosać, A.; Jovanović, V.; Pešović, J.; Brajušković, G.; Dimitrijević, N.; Todorović, S.; Romac, S.; Rašić, V.M.; Savić-Pavićević, D. Joint effect of the SMN2 and SERF1A genes on childhood-onset types of spinal muscular atrophy in Serbian patients. J. Hum. Genet. 2015, 60, 723-728. [CrossRef] [PubMed]

74. Fang, P.; Li, L.; Zeng, J.; Zhou, W.J.; Wu, W.Q.; Zhong, Z.Y.; Yan, T.Z.; Xie, J.S.; Huang, J.; Lin, L.; et al. Molecular characterization and copy number of SMN1, SMN2 and NAIP in Chinese patients with spinal muscular atrophy and unrelated healthy controls. BMC Musculoskel. Disord. 2015, 16, 11. [CrossRef] [PubMed]

75. Stabley, D.L.; Harris, A.W.; Holbrook, J.; Chubbs, N.J.; Lozo, K.W.; Crawford, T.O.; Swoboda, K.J.; Funanage, V.L.; Wang, W.; Mackenzie, W.; et al. SMN1 and SMN2 copy numbers in cell lines derived from patients with spinal muscular atrophy as measured by array digital PCR. Mol. Genet. Genom. Med. 2015, 3, 248-257. [CrossRef]

76. Prior, T.W.; Krainer, A.R.; Hua, Y.; Swoboda, K.J.; Snyder, P.C.; Bridgeman, S.J.; Burghes, A.H.; Kissel, J.T. A positive modifier of spinal muscular atrophy in the SMN2 gene. Am. J. Hum. Genet. 2009, 85, 408-413. [CrossRef]

77. Bernal, S.; Alias, L.; Barcelo, M.; Also-Rallo, E.; Martínez-Hernández, R.; Gámez, J.; Guillén-Navarro, E.; Rosell, J.; Hernando, I.; Rodríguez-Alvarez, F.; et al. The c. 859G> C variant in the SMN2 gene is associated with types II and III SMA and originates from a common ancestor. J. Med. Genet. 2010, 47, 640-642. [CrossRef]

78. Vezain, M.; Saugier-Veber, P.; Goina, E.; Touraine, R.; Manel, V.; Toutain, A.; Fehrenbach, S.; Frébourg, T.; Pagani, F.; Tosi, M.; et al. A rare SMN2 variant in a previously unrecognized composite splicing regulatory element induces exon 7 inclusion and reduces the clinical severity of spinal muscular atrophy. Hum. Mutat. 2010, 31, E1110-E1125. [CrossRef]

79. Burghes, A.H.; Ingraham, S.E.; McLean, M.; Thompson, T.G.; McPherson, J.D.; Kote-Jarai, Z.; Carpten, J.D.; DiDonato, C.J.; Ikeda, J.E.; Surh, L.; et al. A multicopy dinucleotide marker that maps close to the spinal muscular atrophy gene. Genomics 1994, 21, 394-402. [CrossRef]

80. Cobben, J.; Van der Steege, G.; Grootscholten, P.; De Visser, M.; Scheffer, H.; Buys, C. Deletions of the survival motor neuron gene in unaffected siblings of patients with spinal muscular atrophy. Am. J. Hum. Genet. 1995, $57,805$.

81. Hahnen, E.; Forkert, R.; Marke, C.; Rudnik-Schöneborn, S.; Schönling, J.; Zerres, K.; Creavin, T.; Wirth, B. Molecular analysis of candidate genes on chromosome $5 q 13$ in autosomal recessive spinal muscular atrophy: Evidence of homozygous deletions of the SMN gene in unaffected individuals. Hum. Mol. Genet. 1995, 4, 1927-1933. [CrossRef]

82. Ackermann, B.; Kröber, S.; Torres-Benito, L.; Borgmann, A.; Peters, M.; Hosseini Barkooie, S.M.; Tejero, R.; Jakubik, M.; Schreml, J.; Milbradt, J.; et al. Plastin 3 ameliorates spinal muscular atrophy via delayed axon pruning and improves neuromuscular junction functionality. Hum. Mol. Genet. 2013, 22, 1328-1347. [CrossRef]

83. Heesen, L.; Peitz, M.; Torres-Benito, L.; Hölker, I.; Hupperich, K.; Dobrindt, K.; Jungverdorben, J.; Ritzenhofen, S.; Weykopf, B.; Eckert, D.; et al. Plastin 3 is upregulated in iPSC-derived motoneurons from asymptomatic SMN1-deleted individuals. Cell. Mol. Life Sci. 2016, 73, 2089-2104. [CrossRef] [PubMed]

84. Hasanzad, M.; Azad, M.; Kahrizi, K.; Saffar, B.S.; Nafisi, S.; Keyhanidoust, Z.; Azimian, M.; Refah, A.; Urtizberea, J.A.; Tizzano, E.F.; et al. Carrier frequency of SMA by quantitative analysis of the SMN1 deletion in the Iranian population. Eur. J. Neurol. 2010, 17, 160. [CrossRef] [PubMed]

85. Kaifer, K.A.; Villalón, E.; Osman, E.Y.; Glascock, J.J.; Arnold, L.L.; Cornelison, D.; Lorson, C.L. Plastin-3 extends survival and reduces severity in mouse models of spinal muscular atrophy. JCI Insight 2017, 2, e89970. [CrossRef] [PubMed] 
86. McGovern, V.L.; Massoni-Laporte, A.; Wang, X.; Le, T.T.; Le, H.T.; Beattie, C.E.; Rich, M.M.; Burghes, A.H. Plastin 3 expression does not modify spinal muscular atrophy severity in the $\triangle 7$ SMA mouse. PLoS ONE 2015, 10, e0132364. [CrossRef]

87. Hao, L.T.; Wolman, M.; Granato, M.; Beattie, C.E. Survival motor neuron affects plastin 3 protein levels leading to motor defects. J. Neurosci. 2012, 32, 5074-5084. [CrossRef]

88. Janzen, E.; Mendoza-Ferreira, N.; Hosseinibarkooie, S.; Schneider, S.; Hupperich, K.; Tschanz, T.; Grysko, V.; Riessland, M.; Hammerschmidt, M.; Rigo, F.; et al. CHP1 reduction ameliorates spinal muscular atrophy pathology by restoring calcineurin activity and endocytosis. Brain 2018, 141, 2343-2361. [CrossRef]

89. Torres-Benito, L.; Schneider, S.; Rombo, R.; Ling, K.K.; Grysko, V.; Upadhyay, A.; Kononenko, N.L.; Rigo, F.; Bennett, C.F.; Wirth, B. NCALD Antisense oligonucleotide therapy in addition to nusinersen further ameliorates spinal muscular atrophy in mice. Am. J. Hum. Genet. 2019, 105, 221-230. [CrossRef]

90. Hassan, H.A.; Zaki, M.S.; Issa, M.Y.; El-Bagoury, N.M.; Essawi, M.L. Genetic pattern of SMN1, SMN2, and NAIP genes in prognosis of SMA patients. Egypt. J. Med. Hum. Genet. 2020, 21, 1-7. [CrossRef]

91. Essawi, M.; Effat, L.; Shanab, G.; Al-Ettribi, G.; El-Haronui, A.; Karim, A. Molecular analysis of SMN1 and NAIP genes in Egyptian patients with spinal muscular atrophy. Bratislavske lekarske listy 2007, 108, 133.

92. Hauke, J.; Riessland, M.; Lunke, S.; Eyüpoglu, I.Y.; Blümcke, I.; El-Osta, A.; Wirth, B.; Hahnen, E. Survival motor neuron gene 2 silencing by DNA methylation correlates with spinal muscular atrophy disease severity and can be bypassed by histone deacetylase inhibition. Hum. Mol. Genet. 2009, 18, 304-317. [CrossRef] [PubMed]

93. Cao, Y.Y.; Qu, Y.J.; He, S.X.; Li, Y.; Bai, J.L.; Jin, Y.W.; Wang, H.; Song, F. Association between SMN2 methylation and disease severity in Chinese children with spinal muscular atrophy. J. Zhejiang Univ. Sci. B 2016, 17, 76-82. [CrossRef] [PubMed]

94. Zheleznyakova, G.Y.; Voisin, S.; Kiselev, A.V.; Almén, M.S.; Xavier, M.J.; Maretina, M.A.; Tishchenko, L.I.; Fredriksson, R.; Baranov, V.S.; Schiöth, H.B. Genome-wide analysis shows association of epigenetic changes in regulators of Rab and Rho GTPases with spinal muscular atrophy severity. Eur. J. Hum. Genet. 2013, 21, 988-993. [CrossRef] [PubMed]

95. Zheleznyakova, G.Y.; Nilsson, E.K.; Kiselev, A.V.; Maretina, M.A.; Tishchenko, L.I.; Fredriksson, R.; Baranov, V.S.; Schiöth, H.B. Methylation levels of SLC23A2 and NCOR2 genes correlate with spinal muscular atrophy severity. PLoS ONE 2015, 10 e0121964. [CrossRef]

96. Aguilera, O.; Fernández, A.F.; Muñoz, A.; Fraga, M.F. Epigenetics and environment: A complex relationship. J. Appl. Physiol. 2010, 109, 243-251. [CrossRef]

97. Chang, J.G.; Hsieh-Li, H.M.; Jong, Y.J.; Wang, N.M.; Tsai, C.H.; Li, H. Treatment of spinal muscular atrophy by sodium butyrate. Proc. Natl. Acad. Sci. USA 2001, 98, 9808-9813. [CrossRef]

98. Brichta, L.; Hofmann, Y.; Hahnen, E.; Siebzehnrubl, F.; Raschke, H.; Blumcke, I.; Eyupoglu, I.; Wirth, B. Valproic acid increases the SMN2 protein level: A well-known drug as a potential therapy for spinal muscular atrophy. Hum. Mol. Genet. 2003, 12, 2481-2489. [CrossRef]

99. Sumner, C.J.; Huynh, T.N.; Markowitz, J.A.; Perhac, J.S.; Hill, B.; Coovert, D.D.; Schussler, K.; Chen, X.; Jarecki, J.; Burghes, A.H.; et al. Valproic acid increases SMN levels in spinal muscular atrophy patient cells. Ann.Neurol. Offi. J. Am. Neurol. Assoc. Child Neurol. Soc. 2003, 54, 647-654. [CrossRef]

100. Hahnen, E.; Eyüpoglu, I.Y.; Brichta, L.; Haastert, K.; Tränkle, C.; Siebzehnrübl, F.A.; Riessland, M.; Hölker, I.; Claus, P.; Romstöck, J.; et al. In vitro and ex vivo evaluation of second-generation histone deacetylase inhibitors for the treatment of spinal muscular atrophy. J. Neurochem. 2006, 98, 193-202. [CrossRef]

101. Mohseni, J.; Al-Najjar, B.O.; Wahab, H.A.; Zabidi-Hussin, Z.; Sasongko, T.H. Transcript, methylation and molecular docking analyses of the effects of HDAC inhibitors, SAHA and Dacinostat, on SMN2 expression in fibroblasts of SMA patients. J. Hum. Genet. 2016, 61, 823-830. [CrossRef]

102. Riessland, M.; Brichta, L.; Hahnen, E.; Wirth, B. The benzamide M344, a novel histone deacetylase inhibitor, significantly increases SMN2 RNA/protein levels in spinal muscular atrophy cells. Hum. Genet. 2006, 120, 101-110. [CrossRef] [PubMed]

103. Avila, A.M.; Burnett, B.G.; Taye, A.A.; Gabanella, F.; Knight, M.A.; Hartenstein, P.; Cizman, Z.; Di Prospero, N.A.; Pellizzoni, L.; Fischbeck, K.H.; et al. Trichostatin A increases SMN expression and survival in a mouse model of spinal muscular atrophy. J. Clin. Investig. 2007, 117, 659-671. [CrossRef] 
104. Garbes, L.; Riessland, M.; Hölker, I.; Heller, R.; Hauke, J.; Tränkle, C.; Coras, R.; Blümcke, I.; Hahnen, E.; Wirth, B. LBH589 induces up to 10-fold SMN protein levels by several independent mechanisms and is effective even in cells from SMA patients non-responsive to valproate. Hum. Mol. Genet. 2009, 18, 3645-3658. [CrossRef] [PubMed]

105. Pagliarini, V.; Guerra, M.; Di Rosa, V.; Compagnucci, C.; Sette, C. Combined treatment with the histone deacetylase inhibitor LBH589 and a splice-switch antisense oligonucleotide enhances SMN2 splicing and SMN expression in Spinal Muscular Atrophy cells. J. Neurochem. 2020, 153, 264-275. [CrossRef] [PubMed]

106. Swoboda, K.J.; Scott, C.B.; Reyna, S.P.; Prior, T.W.; LaSalle, B.; Sorenson, S.L.; Wood, J.; Acsadi, G.; Crawford, T.O.; Kissel, J.T.; et al. Phase II open label study of valproic acid in spinal muscular atrophy. PLoS ONE 2009, 4, e5268. [CrossRef]

107. Swoboda, K.J.; Scott, C.B.; Crawford, T.O.; Simard, L.R.; Reyna, S.P.; Krosschell, K.J.; Acsadi, G.; Elsheik, B.; Schroth, M.K.; D’Anjou, G.; et al. SMA CARNI-VAL trial part I: Double-blind, randomized, placebo-controlled trial of L-carnitine and valproic acid in spinal muscular atrophy. PLoS ONE 2010, 5 e12140. [CrossRef]

108. Krosschell, K.J.; Kissel, J.T.; Townsend, E.L.; Simeone, S.D.; Zhang, R.Z.; Reyna, S.P.; Crawford, T.O.; Schroth, M.K.; Acsadi, G.; Kishnani, P.S.; et al. Clinical trial of L-Carnitine and valproic acid in spinal muscular atrophy type I. Muscle Nerve 2018, 57, 193-199. [CrossRef]

109. Kissel, J.T.; Scott, C.B.; Reyna, S.P.; Crawford, T.O.; Simard, L.R.; Krosschell, K.J.; Acsadi, G.; Elsheik, B.; Schroth, M.K.; D'Anjou, G.; et al. SMA carni-VAL trial part II: A prospective, single-armed trial of L-carnitine and valproic acid in ambulatory children with spinal muscular atrophy. PLoS ONE 2011, 6, e21296. [CrossRef]

110. Kissel, J.T.; Elsheikh, B.; King, W.M.; Freimer, M.; Scott, C.B.; Kolb, S.J.; Reyna, S.P.; Crawford, T.O.; Simard, L.R.; Krosschell, K.J.; et al. SMA valiant trial: A prospective, double-blind, placebo-controlled trial of valproic acid in ambulatory adults with spinal muscular atrophy. Muscle Nerve 2014, 49, 187-192. [CrossRef]

111. Darbar, I.A.; Plaggert, P.G.; Resende, M.B.D.; Zanoteli, E.; Reed, U.C. Evaluation of muscle strength and motor abilities in children with type II and III spinal muscle atrophy treated with valproic acid. BMC Neurol. 2011, 11, 36. [CrossRef]

112. Elshafay, A.; Hieu, T.H.; Doheim, M.F.; Kassem, M.A.M.; ELdoadoa, M.F.; Holloway, S.K.; Abo-Elghar, H.; Hirayama, K.; Huy, N.T. Efficacy and safety of valproic acid for spinal muscular atrophy: A systematic review and meta-analysis. CNS Drugs 2019, 33, 239-250. [CrossRef]

113. Brahe, C.; Vitali, T.; Tiziano, F.D.; Angelozzi, C.; Pinto, A.M.; Borgo, F.; Moscato, U.; Bertini, E.; Mercuri, E.; Neri, G. Phenylbutyrate increases SMN gene expression in spinal muscular atrophy patients. Eur. J. Hum. Genet. 2005, 13, 256-259. [CrossRef]

114. Mercuri, E.; Bertini, E.; Messina, S.; Pelliccioni, M.; D’Amico, A.; Colitto, F.; Mirabella, M.; Tiziano, F.D.; Vitali, T.; Angelozzi, C.; et al. Pilot trial of phenylbutyrate in spinal muscular atrophy. Neuromuscul. Disord. 2004, 14, 130-135. [CrossRef]

115. Mercuri, E.; Bertini, E.; Messina, S.; Solari, A.; D’amico, A.; Angelozzi, C.; Battini, R.; Berardinelli, A.; Boffi, P.; Bruno, C.; et al. Randomized, double-blind, placebo-controlled trial of phenylbutyrate in spinal muscular atrophy. Neurology 2007, 68, 51-55. [CrossRef]

116. Liu, Q.; Dreyfuss, G. A novel nuclear structure containing the survival of motor neurons protein. EMBO J. 1996, 15, 3555-3565. [CrossRef]

117. Li, D.K.; Tisdale, S.; Lotti, F.; Pellizzoni, L. SMN control of RNP assembly: From post-transcriptional gene regulation to motor neuron disease. Semin. Cell Dev. Biol. 2014, 32, 22-29. [CrossRef]

118. Hensel, N.; Claus, P. The actin cytoskeleton in SMA and ALS: How does it contribute to motoneuron degeneration? Neuroscientist 2018, 24, 54-72. [CrossRef]

119. Donlin-Asp, P.G.; Bassell, G.J.; Rossoll, W. A role for the survival of motor neuron protein in mRNP assembly and transport. Curr. Opin. Neurobiol. 2016, 39, 53-61. [CrossRef]

120. Groen, E.J.; Gillingwater, T.H. UBA1: At the crossroads of ubiquitin homeostasis and neurodegeneration. Trends Mol. Med. 2015, 21, 622-632. [CrossRef]

121. Boyd, P.J.; Tu, W.Y.; Shorrock, H.K.; Groen, E.J.; Carter, R.N.; Powis, R.A.; Thomson, S.R.; Thomson, D.; Graham, L.C.; Motyl, A.A.; et al. Bioenergetic status modulates motor neuron vulnerability and pathogenesis in a zebrafish model of spinal muscular atrophy. PLoS Genet. 2017, 13, e1006744. [CrossRef] 
122. Kong, L.; Wang, X.; Choe, D.W.; Polley, M.; Burnett, B.G.; Bosch-Marcé, M.; Griffin, J.W.; Rich, M.M.; Sumner, C.J. Impaired synaptic vesicle release and immaturity of neuromuscular junctions in spinal muscular atrophy mice. J. Neurosci. 2009, 29, 842-851. [CrossRef] [PubMed]

123. Akten, B.; Kye, M.J.; Hao, L.T.; Wertz, M.H.; Singh, S.; Nie, D.; Huang, J.; Merianda, T.T.; Twiss, J.L.; Beattie, C.E.; et al. Interaction of survival of motor neuron (SMN) and HuD proteins with mRNA cpg15 rescues motor neuron axonal deficits. Proc. Natl. Acad. Sci. USA 2011, 108, 10337-10342. [CrossRef] [PubMed]

124. Fallini, C.; Zhang, H.; Su, Y.; Silani, V.; Singer, R.H.; Rossoll, W.; Bassell, G.J. The survival of motor neuron $(\mathrm{SMN})$ protein interacts with the mRNA-binding protein $\mathrm{HuD}$ and regulates localization of poly (A) mRNA in primary motor neuron axons. J. Neurosci. 2011, 31, 3914-3925. [CrossRef] [PubMed]

125. Ottesen, E.W.; Singh, N.N.; Luo, D.; Singh, R.N. High-affinity RNA targets of the Survival Motor Neuron protein reveal diverse preferences for sequence and structural motifs. Nucleic Acids Res. 2018, 46, 10983-11001. [CrossRef] [PubMed]

126. Hamilton, G.; Gillingwater, T.H. Spinal muscular atrophy: Going beyond the motor neuron. Trends Mol. Med. 2013, 19, 40-50. [CrossRef]

127. Besse, A.; Astord, S.; Marais, T.; Roda, M.; Giroux, B.; Lejeune, F.X.; Relaix, F.; Smeriglio, P.; Barkats, M.; Biferi, M.G. AAV9-mediated expression of SMN restricted to neurons does not rescue the spinal muscular atrophy phenotype in mice. Mol. Ther. 2020. [CrossRef]

128. Ramos, D.M.; d'Ydewalle, C.; Gabbeta, V.; Dakka, A.; Klein, S.K.; Norris, D.A.; Matson, J.; Taylor, S.J.; Zaworski, P.G.; Prior, T.W.; et al. Age-dependent SMN expression in disease-relevant tissue and implications for SMA treatment. J. Clin. Investig. 2019, 129, 4817-4831. [CrossRef]

129. Wadman, R.I.; Stam, M.; Jansen, M.D.; van der Weegen, Y.; Wijngaarde, C.A.; Harschnitz, O.; Sodaar, P.; Braun, K.P.; Dooijes, D.; Lemmink, H.H.; et al. A comparative study of SMN protein and mRNA in blood and fibroblasts in patients with spinal muscular atrophy and healthy controls. PLoS ONE 2016, 11, e0167087. [CrossRef]

130. Khalil, M.; Teunissen, C.E.; Otto, M.; Piehl, F.; Sormani, M.P.; Gattringer, T.; Barro, C.; Kappos, L.; Comabella, M.; Fazekas, F.; et al. Neurofilaments as biomarkers in neurological disorders. Nat. Rev. Neurol. 2018, 14, 577-589. [CrossRef]

131. Petzold, A. Neurofilament phosphoforms: Surrogate markers for axonal injury, degeneration and loss. J. Neurol. Sci. 2005, 233, 183-198. [CrossRef]

132. Yuan, A.; Rao, M.; Veeranna Nixon, R. Neurofilaments and neurofilament proteins in health and disease. Cold Spring Harb. Perspect. Biol. 2017, 9, a018309. [CrossRef] [PubMed]

133. Goldstein, M.E.; Sternberger, N.H.; Sternberger, L.A. Phosphorylation protects neurofilaments against proteolysis. J. Neuroimmunol. 1987, 14, 149-160. [CrossRef]

134. Darras, B.T.; Crawford, T.O.; Finkel, R.S.; Mercuri, E.; De Vivo, D.C.; Oskoui, M.; Tizzano, E.F.; Ryan, M.M.; Muntoni, F.; Zhao, G.; et al. Neurofilament as a potential biomarker for spinal muscular atrophy. Ann. Clin. Transl. Neurol. 2019, 6, 932-944. [CrossRef]

135. Wurster, C.D.; Steinacker, P.; Günther, R.; Koch, J.C.; Lingor, P.; Uzelac, Z.; Witzel, S.; Wollinsky, K.; Winter, B.; Osmanovic, A.; et al. Neurofilament light chain in serum of adolescent and adult SMA patients under treatment with nusinersen. J. Neurol. 2019, 267, 36-44. [CrossRef]

136. Totzeck, A.; Stolte, B.; Kizina, K.; Bolz, S.; Schlag, M.; Thimm, A.; Kleinschnitz, C.; Hagenacker, T. Neurofilament heavy chain and tau protein are not elevated in cerebrospinal fluid of adult patients with spinal muscular atrophy during loading with nusinersen. Int. J. Mol. Sci. 2019, 20, 5397. doi:10.3390/ijms20215397. [CrossRef]

137. Blennow, K.; Hampel, H.; Weiner, M.; Zetterberg, H. Cerebrospinal fluid and plasma biomarkers in Alzheimer disease. Nat. Rev. Neurol. 2010, 6, 131. [CrossRef]

138. Olsson, B.; Lautner, R.; Andreasson, U.; Öhrfelt, A.; Portelius, E.; Bjerke, M.; Hölttä, M.; Rosén, C.; Olsson, C.; Strobel, G.; et al. CSF and blood biomarkers for the diagnosis of Alzheimer's disease: A systematic review and meta-analysis. Lancet Neurol. 2016, 15, 673-684. doi:10.1016/S1474-4422(16)00070-3. [CrossRef]

139. Scarafino, A.; D’Errico, E.; Introna, A.; Fraddosio, A.; Distaso, E.; Tempesta, I.; Morea, A.; Mastronardi, A.; Leante, R.; Ruggieri, M.; et al. Diagnostic and prognostic power of CSF Tau in amyotrophic lateral sclerosis. J. Neurol. 2018, 265, 2353-2362. [CrossRef] [PubMed] 
140. Winter, B.; Guenther, R.; Ludolph, A.C.; Hermann, A.; Otto, M.; Wurster, C.D. Neurofilaments and tau in CSF in an infant with SMA type 1 treated with nusinersen. J. Neurol. Neurosurg. Psychiatry 2019, 90, 1068-1069. [CrossRef]

141. Kim, J.K.; Jha, N.N.; Feng, Z.; Faleiro, M.R.; Chiriboga, C.A.; Wei-Lapierre, L.; Dirksen, R.T.; Ko, C.P.; Monani, U.R. Muscle-specific SMN reduction reveals motor neuron-Independent disease in spinal muscular atrophy models. J. Clin. Investig. 2020, 130, 1271-1287. [CrossRef]

142. Fayzullina, S.; Martin, L.J. Skeletal muscle DNA damage precedes spinal motor neuron DNA damage in a mouse model of Spinal Muscular Atrophy (SMA). PLoS ONE 2014, 9, e93329. [CrossRef]

143. Alves, C.R.; Zhang, R.; Johnstone, A.J.; Garner, R.; Nwe, P.H.; Siranosian, J.J.; Swoboda, K.J. Serum creatinine is a biomarker of progressive denervation in spinal muscular atrophy. Neurology 2020, 94, e921-e931. [CrossRef] [PubMed]

144. Finkel, R.S.; Crawford, T.O.; Swoboda, K.J.; Kaufmann, P.; Juhasz, P.; Li, X.; Guo, Y.; Li, R.H.; Trachtenberg, F.; Forrest, S.J.; et al. Candidate proteins, metabolites and transcripts in the Biomarkers for Spinal Muscular Atrophy (BforSMA) clinical study. PLoS ONE 2012, 7 e35462. [CrossRef] [PubMed]

145. Ng, S.Y.; Soh, B.S.; Rodriguez-Muela, N.; Hendrickson, D.G.; Price, F.; Rinn, J.L.; Rubin, L.L. Genome-wide RNA-Seq of human motor neurons implicates selective ER stress activation in spinal muscular atrophy. Cell Stem Cell 2015, 17, 569-584. [CrossRef] [PubMed]

146. Rizzo, F.; Nizzardo, M.; Vashisht, S.; Molteni, E.; Melzi, V.; Taiana, M.; Salani, S.; Santonicola, P.; Di Schiavi, E.; Bucchia, M.; et al. Key role of SMN/SYNCRIP and RNA-Motif 7 in spinal muscular atrophy: RNA-Seq and motif analysis of human motor neurons. Brain 2019, 142, 276-294. [CrossRef]

147. Nizzardo, M.; Taiana, M.; Rizzo, F.; Benitez, J.A.; Nijssen, J.; Allodi, I.; Melzi, V.; Bresolin, N.; Comi, G.; Hedlund, E.; et al. Synaptotagmin 13 is neuroprotective across motor neuron diseases. Acta Neuropathol. 2020, 139, 837-853. [CrossRef]

148. Malone, E.R.; Oliva, M.; Sabatini, P.J.; Stockley, T.L.; Siu, L.L. Molecular profiling for precision cancer therapies. Genome Med. 2020, 12, 8. [CrossRef]

149. Besser, J.; Carleton, H.A.; Gerner-Smidt, P.; Lindsey, R.L.; Trees, E. Next-generation sequencing technologies and their application to the study and control of bacterial infections. Clin. Microbiol. Infect. 2018, 24, 335-341. [CrossRef]

150. Allicock, O.M.; Guo, C.; Uhlemann, A.C.; Whittier, S.; Chauhan, L.V.; Garcia, J.; Price, A.; Morse, S.S.; Mishra, N.; Briese, T.; et al. BacCapSeq: A platform for diagnosis and characterization of bacterial infections. MBio 2018, 9, e02007-18. [CrossRef]

151. Gibbs, R.M.; Lipnick, S.; Bateman, J.W.; Chen, L.; Cousins, H.C.; Hubbard, E.G.; Jowett, G.; LaPointe, D.S.; McGredy, M.J.; Odonkor, M.N.; et al. Toward precision medicine for neurological and neuropsychiatric disorders. Cell Stem Cell 2018, 23, 21-24. [CrossRef]

152. Seferian, A.M.; Moraux, A.; Canal, A.; Decostre, V.; Diebate, O.; Le Moing, A.G.; Gidaro, T.; Deconinck, N.; Van Parys, F.; Vereecke, W.; et al. Upper limb evaluation and one-year follow up of non-ambulant patients with spinal muscular atrophy: An observational multicenter trial. PLoS ONE 2015, 10, e0121799. [CrossRef] [PubMed]

(C) 2020 by the authors. Licensee MDPI, Basel, Switzerland. This article is an open access article distributed under the terms and conditions of the Creative Commons Attribution (CC BY) license (http://creativecommons.org/licenses/by/4.0/). 